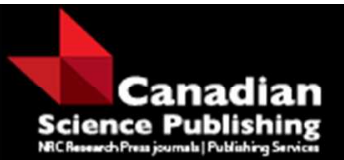

Canadian Journal of Forest Research Revue canadienne de recherche forestière

\title{
Biomass equations for lodgepole pine in northern Sweden
}

\begin{tabular}{|r|l|}
\hline Journal: & Canadian Journal of Forest Research \\
\hline Manuscript ID & cjfr-2016-0131.R2 \\
\hline Manuscript Type: & Article \\
\hline Date Submitted by the Author: & 15 -Sep-2016 \\
\hline Keyword: List of Authors: & $\begin{array}{l}\text { Elfving, Björn; Swedish University of Agricultural Sciences, Department of } \\
\text { Forest Ecology and Management } \\
\text { Ahnlund Ulvcrona, Kristina; Swedish University of Agricultural Scienses, } \\
\text { Forest Biomaterials and Technology } \\
\text { Egnell, Gustaf; Swedish University of Agricultural Sciences, Forest Ecology } \\
\text { and Management }\end{array}$ \\
\hline & $\begin{array}{l}\text { destructive biomass sampling, allometric functions, above-ground biomass, } \\
\text { comparison to natural stands, comparison to Scots pine }\end{array}$ \\
\hline
\end{tabular}

\section{SCHOLARONE ${ }^{m}$}

Manuscripts 
2 Biomass equations for lodgepole pine in northern Sweden

5 Björn Elfving ${ }^{1}$, Kristina Ahnlund Ulvcrona $^{2}$ and Gustaf Egnell ${ }^{3}$

6

$7 \quad{ }^{1}$ Department of Forest Ecology and Management, Swedish University of Agricultural Sciences.

$8 \quad$ Umeå. bjorn.elfving@slu.se phone number: +46(0)90-7868222

$9{ }^{2}$ Department of Forest Biomaterials and Technology, Swedish University of Agricultural

10 Sciences. Umeå. kristina.ulvcrona@slu.se phone number: +46(0)70-6515456

11

$12{ }^{3}$ Department of Forest Ecology and Management, Swedish University of Agricultural Sciences.

13 Umeå. gustaf.egnell@slu.se phone number: +46(0)90-7868455

14

15

16

17

18

19

20

21 
23 Abstract

24 Biomass equations for cultivated lodgepole pine (Pinus contorta var. latifolia) were developed 25 based on data from destructive biomass sampling of 164 trees collected from 13 sites at latitudes $26 \quad 61.9-66.2^{\circ} \mathrm{N}$ in northern Sweden. Stand age varied between $20-87$ years and top height between $27 \quad 8-32 \mathrm{~m}$. Seeded and planted stands with different densities were included. Allometric biomass 28 equations for all above-stump components were constructed, expressing dry weight of stem, 29 bark, living and dead branch wood, foliage and cones, as well as total weight. Equations with 1-3

30 independent variables were constructed for each component, accounting variances within and 31 between sites. Estimated values for trees of different sizes were compared to corresponding 32 estimates for lodgepole pine in Canada and Scots pine in Sweden and Finland. Residual variation 33 of our equations was lower than that of equations from other sources. Our equations predicted 34 similar average biomass levels as Canadian equations for natural stands. In comparison to Scots 35 pine, at given stem dimensions, lodgepole pine had 50-100\% more foliage biomass and greater 36 dead branch biomass with increasing tree size. The wide amplitude of our data and the flexible 37 form of our equations should make them useful for wider application.

Keywords: destructive biomass sampling, allometric functions 


\section{Introduction}

46 The growing market for bioenergy in the Nordic countries has targeted forest biomass as an

47 important feedstock (Ericsson et al. 2004). This, together with expectations relating to a future

48 bioeconomy (Octave and Thomas 2009) and carbon stock reporting under the Kyoto protocol,

49 has increased the need for tools to estimate the biomass carbon (C) stocks and energy assets of

50 forests. The $\mathrm{C}$ stock and energy assets are highly correlated with dry weight (DW) and can be

51 estimated with biomass equations. Such equations express the dry weight of different

52 components of the tree as a function of easily measured variables like diameter, height and

53 crown length. Different species differ with respect to wood density (Cannell 1989; Zobel and van

54 Buijtenen 1989) and allocation pattern. i.e. crown structure and stem form (Satoo and Madgwick

55 1982). Thus, separate functions are needed for each species. Biomass equations for Scots pine

56 (Pinus sylvestris L.), Norway spruce (Picea abies (L.) H. Karst) and birch (Betula spp.) in

57 Sweden and Finland have already been developed (Marklund 1988; Claesson et al. 2001;

58 Peterson and Ståhl 2006; Repola 2008; 2009; Repola and Ulvcrona 2014), but no equations are

59 available for lodgepole pine (Pinus contorta Dougl.).

60 As the inland form of lodgepole pine (Pinus contorta var. latifolia), introduced to Sweden from

61 western Canada on a large scale after 1970 (Elfving et al. 2001), starts to yield significant

62 amounts of biomass there is an urgent need for locally adapted biomass equations for this

63 species. Biomass equations for lodgepole pine are available (Brown 1978; Gholz et al. 1979;

64 Manning et al. 1984), but these equations are based on naturally regenerated trees from North

65 America, and until now the dominant method of regeneration in Sweden has been planting, 
resulting in trees with different allocation of branches and foliage compared to naturally regenerated ones (Long and Smith 1992; Litton et al. 2003).

In a review of available biomass equations, Ter-Mikaelian and Korzukhin (1997) reported two individual studies with biomass equations for lodgepole pine from the grey literature (Brown 1978; Gholz et al. 1979). Both studies are limited in terms of number of sample trees/stands, tree size and biomass fractions analyzed. In both studies three equations are presented i.e. for stemwood including bark, needles and branches. The study by Brown (1978) is based on only eight sample trees in the diameter range $1-5 \mathrm{~cm}$. The study by Gholz et al. (1979) is limited to 29 sample trees with a diameter range from 3-29 $\mathrm{cm}$. The grey literature also provides a larger study by Manning et al. (1984), where biomass equations for lodgepole pine are presented for stemwood, stem bark, branches (diam. $>0.5 \mathrm{~cm})$, twigs (diam. $<0.5 \mathrm{~cm})$ including foliage, and for all above-stump biomass. The data behind the equations originated from 149 sample trees collected from four ecoregions in the Yukon Territory with a diameter range between 3 and 36 $\mathrm{cm}$. The limited information about site and stand characteristics, including regeneration method and stem density, makes it difficult to judge whether these equations are useful for Swedish conditions where most stands are regenerated by planting.

Based on a thorough review and published data on biomass equations for a number of North American tree species, including lodgepole pine, Jenkins et al. (2003) developed generalized biomass equations for conifers and broadleaves to be used for e.g. large scale inventory-based C budgets. Their work was further developed by Chojnacky et al. (2014) and included an update of published data. In both studies, pseudodata were generated within the diameter limitations of published equations. The pseudodata were then used to construct generalized total biomass equations over the full diameter range based on a two-parameter logarithmic regression model 

102 lodgepole pine.

with diameter at breast height $(\mathrm{DBH})$ as the independent variable $(\ln ($ biomass $)=\beta 0+\beta 1 \mathrm{x}$ $\ln (\mathrm{DBH}))$. With all the uncertainties included in such an approach, Chojnacky et al. (2014) concluded the need for better data to be collected across the distribution ranges of different tree species and Jenkins et al. (2003) suggested a common protocol for biomass estimate studies and that researchers, in addition to publishing their biomass equations, also published the data from which their equations were developed.

Thus, despite inclusion of unpublished reports, we found few studies relating to lodgepole pine, and those found were mostly based on few and small trees. No new, more comprehensive studies have been found. It appears that there is a world-wide need for biomass equations for lodgepole pine. Here we present such equations for different fractions of lodgepole pine trees based on 164 sample trees sampled in 13 stands in Sweden and we include the data behind the equations as an appended Excel-file. The equations are compared with the equations published by Manning et al. (1984) to indicate whether they could also be useful for estimates within the natural range of

\section{Material and methods}

The sample trees were collected in northern Sweden, from latitude $61.9^{\circ} \mathrm{N}$ in the south to

107 latitude $66.2^{\circ} \mathrm{N}$ in the north (Figure 1, Table 1). Altitude varied between 80 and 440 metres

108 above sea level and stand age between 20 and 87 years. Number of stems ha ${ }^{-1}$ varied between

109450 and 6034, basal area between 12 and $51 \mathrm{~m}^{2} \mathrm{ha}^{-1}$ and top height between 8 and $32 \mathrm{~m}$ (Table

110 1). The distributions of sample trees over height- and diameter classes are given in Table 2. 
111 Some sites hosted long-term yield plots in field experiments but sample trees were only affected

112 by applied treatments in two of them: the spacing trial 1209 at Långsjönäset and the scarification

113 trial 1544 at Degerön. At Långsjönäset the square spacings 1.1, 1.6, 2.0, 2.85 and $4.0 \mathrm{~m}$ were

114 represented and sample trees were selected from all spacings. At Degerön the treatments were

115 ordinary patch scarification and deep ploughing on a poor sediment of deep sand and the

116 sampling included both treatments. The sites Toböle 2 and Korseleberget represent the first

117 plantations of lodgepole pine in Sweden established in 1931 (Toböle 2) and 1928

118 (Korseleberget).

119

$120<$ Figure 1 here $>$

$121<$ Table 1 here $>$

$122<$ Table 2 here $>$

123

$124 \quad 2.2$ Sampling procedure

125 In total, 164 trees were sampled from 13 different sites during the years 1999-2012 (Table 1).

126 The same sampling procedure was applied in all but one study (Toböle 1999). First the main

127 procedure used is described and after that the deviations for the Toböle 1999 study.

128 Sample trees were selected by stratified (by DBH) random sampling among undamaged trees in

129 each plot. Forked trees and trees at stand borders were avoided. Diameter at breast height (DBH,

130 diameter over bark at $1.3 \mathrm{~m}$ above ground, $\mathrm{cm}$ ) was marked and cross-callipered to the nearest

$131 \mathrm{~mm}$ before felling. The aim of the biomass sampling was to estimate dry weight above ground, 
132 and therefore each sample tree was cut down as close to the ground as possible. Measurements of

133 the felled trees included total stem length $(\mathrm{L}, \mathrm{m})$ and distance from stem base to the living crown,

134 defined as the lowest living branch separated from other living branches by less than three

135 whorls. Diameter was cross-callipered at the base of the stem, and at each metre up to the top.

136 The living crown was divided into four sections, each of which accounted for $25 \%$ of the crown

137 length (Figure 2). One branch ocularly judged to be representative of each section was selected

138 and cut using pruning shears. In addition, a representative dead branch was selected from below

139 the living crown of each sample tree. Stem discs (5 cm thick) were cut with a bow saw (scar

140 width $1.5 \mathrm{~mm}$ ) or a chain saw (scar width $8 \mathrm{~mm}$ used for the larger trees) from the butt end of the

141 stem, at breast height $(1.3 \mathrm{~m})$, and at four positions representing $30,55,70$ and $85 \%$ of the total

142 stem length (Figure 2). Scar widths were estimated by comparing the weight of some pieces of

143 wood before slicing with the different saws with the weight of the resulting discs. The saw-dust

144 lost with the chain saw was compensated for but not that from the bow saw. Directly after felling

145 and dividing a tree the sample discs and sample branches were weighed in the field on a

146 laboratory balance $(6 \mathrm{~kg}$ maximum, $\pm 0.0005 \mathrm{~kg}$ ) to obtain the fresh weight. The remaining stem

147 sections and all other branches from each section were weighed on a scale $(30 \mathrm{~kg}$ maximum, \pm

$1480.002 \mathrm{~kg}$ ). For the sampling in Toböle and Korseleberget in 2012, a scale with $100 \mathrm{~kg}$ maximum

149 was used for the remaining stem sections and branches. All sample branches and disc samples

150 for individual sample trees were put in separate airtight plastic bags and within 8 hours from the

151 time of tree felling, the samples were placed in a freezer $\left(-20^{\circ} \mathrm{C}\right)$, where they were stored until it

152 was time to determine their dry weight. 
156 The sectioning of the stem was used to estimate the stem volume and served as a back-up for

157 checking the stem form and weight. Stem volume over bark $\left(\mathrm{V}, \mathrm{dm}^{3}\right)$ was estimated as: where $d_{i}$ is the diameter $(\mathrm{mm})$ at the upper end of each $1-\mathrm{m}$ stem section and $\mathrm{d}_{0}$ is the diameter at the lower end of the first section. This corresponds to Huber's formula with addition of an approximation for the bottom half-meter section.

164 For nine of the sites (in total 119 sample trees) the bark was separated from the discs in the 165 laboratory, and both fractions were immediately weighed on a laboratory balance $(6 \mathrm{~kg}$ 166 maximum, $\pm 0.0005 \mathrm{~kg}$ ) to obtain separate fresh weights for the disc (wood) and the bark. Discs

167 and bark, or discs including the bark, were dried in a ventilated oven at $85^{\circ} \mathrm{C}$ for 48 hours before 168 measuring their dry weight. The discs where then further dried until their weight didn't decrease 169 any more. For living branches, foliage was separated from the branches after 24 hours of drying 170 in a ventilated oven $\left(85^{\circ} \mathrm{C}\right)$, whereas the cones were combined with the branches. The different 171 fractions were then further dried for another 24 hours before weighing. Dead branches were 172 treated as one fraction without needles and were dried in a ventilated oven at $85^{\circ} \mathrm{C}$ for 48 hours 173 before measuring their dry weight.

174 Dry weights for biomass components $\left(\mathrm{DW}_{\mathrm{x}}, \mathrm{kg}\right.$ dry weight per tree) were estimated from 175 measured data as follows, where all disc and section values include bark: 
176 Stem including bark $\left(\mathrm{DW}_{\text {stem }}\right)$

177

178

(2) $\quad \mathrm{DW}_{\text {stem }}=\sum\left(\frac{\left(\frac{\left.D W_{\text {disc } i}+\frac{D W_{\text {disc } i+1}}{F W_{\text {disc } i}}\right)}{2}\right) \times F W_{\text {disc } i+1} \text { stem section } i}{}+D W_{\text {disc } i}\right)$

179

180 where $D W_{\text {disc } i}$ is the dry weight of disc $i, F W_{\text {disc } i}$ is the fresh weight of disc $i, F W_{\text {stem }}$ section $i$ is the fresh weight of the stem section with $i$ in the range 1 to 6 including all stem sections from stump to top. For $i=6$ the index $i+1$ was reduced to 6 .

183

$\operatorname{Bark}\left(\mathrm{DW}_{\text {bark }}\right)$

184

185

(3) $\quad \mathrm{DW}_{\text {bark }}=\Sigma\left(\frac{\left(\frac{\left.D W_{\text {bark } i}+\frac{D W_{\text {bark } i+1}}{F W_{\text {disc } i}}\right)}{2}\right)}{2} \times F W_{\text {stem section } i}+D W_{\text {bark } i} i\right)$

186 where $D W_{\text {bark } i}$ is dry weight of the bark of disc $i$. Other acronyms are as defined

188 under equation (2).

189

$$
\text { Living branches }\left(\mathrm{DW}_{\mathrm{lbr}}\right)
$$

190

191 

where $F W_{\text {stratum } j}$ is the fresh weight for stratum $j$ including the sample branch, with $j$ in the range 1-4. $D W_{s b w . j}$ is the dry weight of the sample of branch wood including cones and $F W_{s b . j}$ is the fresh weight of the sample branch.

$$
\mathrm{DW}_{\mathrm{fol}}=\sum F W_{\text {stratum.j }} \times\left(\frac{D W_{s b f . j}}{F W_{s b . j}}\right)
$$
acronyms are as defined under equation (4).

(6) $\quad \mathrm{DW}_{\mathrm{dbr}}=F W_{D B} \times\left(\frac{D W_{d s b}}{F W_{d s b}}\right)$

$$
\mathrm{DW}_{\text {cone }}=\sum F W_{\text {stratum. } . j} \times\left(\frac{D W_{s b c . j}}{F W_{s b j}}\right)
$$


where $D W_{s b c . j}$ is the dry weight of cones on the sample branch $j$ and other acronyms are as defined under equation (4).

215 For the Toböle site sampling in 1999, a slightly different sampling procedure was used (Elfving,

216 2002). Diameter at breast height was marked and cross-callipered to the nearest $\mathrm{mm}$ before

217 felling. Tree height was measured, and stump height was marked at $1 \%$ of tree height before

218 felling. After felling, the length of the stem was measured. All dead branches were directly

219 gathered and weighted and a representative sample of about $1 \mathrm{~kg}$ was selected for dry weight

220 determination in the laboratory. All living branches were divided into branch fractions with and

221 without needles. Total fresh weight was determined for both groups, representative samples

222 (about $1 \mathrm{~kg}$ ) were selected from each group and their fresh and dry weights were determined.

223 Stem discs $5 \mathrm{~cm}$ thick were cut at $1.5 \mathrm{~m}$ and then every $3 \mathrm{~m}$ up the stem. Drying of the samples

224 to determine dry weight followed the same procedure as above. Stem volume was estimated as

$2253 \pi / 4$ times the sum of squared disc diameters, and stem biomass as volume times mean wood

226 density according to the basal area weighted mean of the stem discs.

227 By convention, stump height is generally defined as $1 \%$ of tree height. In this study only the

228 length from stump to tree top on the felled tree (L, m) was measured (except at Toböle 1999

229 when tree height was measured for the standing tree). To ensure conformity with other studies,

230 measured data was adjusted as follows. Tree height above ground $(\mathrm{H}, \mathrm{m})$ was estimated as $\mathrm{H}=$ $231 \quad \mathrm{~L} / 0.99$.

$232 \quad 2.3$ Statistics 
233 Allometric biomass equations of the form $\ln (Y)=b_{0}+b_{1} \cdot \ln \left(x_{1}\right)+b_{2} \cdot \ln \left(x_{2}\right) \ldots$ were estimated for 234 dry weight $(\mathrm{kg})$ of the total tree above-stump $\left(\mathrm{DW}_{\text {tot }}\right)$ and for the components stem with bark 235 (DW $\left.\mathrm{DWm}_{\text {stem }}\right)$, living branches $\left(\mathrm{DW}_{\mathrm{lbr}}\right)$, dead branches $\left(\mathrm{DW}_{\mathrm{dbr}}\right)$ and foliage $\left(\mathrm{DW}_{\mathrm{fol}}\right)$ using the 236 procedure MIXED in the SAS statistical package. Two-three levels of equations were estimated 237 for each component including different numbers of explanatory variables: (1) only based on $238 \mathrm{DBH},(2)$ based on DBH and H, (3) based on DBH, H and crown length (crl). Appropriate forms 239 of the partial relationships were found by residual studies. The within and between site variation 240 was separated with the MIXED procedure, specifying site as a random class variable according 241 to the model:

(8) $\quad \ln \mathrm{Y}_{\mathrm{ij}}=\mathrm{b} \times \mathrm{X}_{\mathrm{ij}}+\mathrm{u}_{\mathrm{j}}+\mathrm{e}_{\mathrm{ij}}$

where $Y_{i j}$ is measured biomass of actual component for tree $i$ at site $j, b$ is a vector of coefficients, $X_{i j}$ is a vector of explanatory variables, $u_{j}$ is the random effect for site $\mathrm{j}$ and $\mathrm{e}_{\mathrm{ij}}$ is the random effect for tree $\mathrm{i}$ at site $\mathrm{j}$. It is assumed that $\mathrm{u}_{\mathrm{i}}$ and $\mathrm{e}_{\mathrm{ij}}$ are un-correlated and have normal distributions with mean $=0$. The error terms are model parameters which variances

For the partial relationship with $\mathrm{DBH}$, the transformations $\ln (\mathrm{DBH})$ and $\mathrm{DBH} /(\mathrm{DBH}+\mathrm{x})$ were tested, with a search process to find the most appropriate value of $\mathrm{x}$ for each biomass component.

251 The latter formulation was used by Marklund (1988) and Repola (2008, 2009) for Scots pine, 252 Norway spruce and birch ssp. biomass in Sweden and Finland. The differences were marginal for 253 our data and the first form was chosen since it performed well for all components. Tree height 254 was an important variable for estimating biomass of all components except that of dead branches 
255 while crown length was important for estimating branch- and foliage biomass. To get an 256 appropriate partial relationship of stem biomass to height, both height $(\ln \mathrm{H})$ and height above 257 breast height $(\ln (\mathrm{H}-1.3))$ were included for this component as well as in the equation for total 258 biomass. The most commonly applied volume equations for pine and spruce in Sweden (Brandel 259 1990) also include this partial relationship of stem volume to height. Since stem biomass and 260 stem volume are closely related it seems as if this form of the relation between stem size and 261 height is quite general.

262 The variable $\mathrm{H} /(\mathrm{DBH})$ describes stem form (slenderness) and was more significant than $\ln (\mathrm{H})$

263 for estimating the foliage biomass. Since logarithmic transformation causes bias in the absolute 264 scale, the additive coefficients in the equations were adjusted by including the following 265 correction (adj), according to Snowdon (1991):

$$
\operatorname{adj}=\ln \left(\Sigma D W_{\text {obs }}\right)-\ln \left(\Sigma \exp \left(\ln \left(\mathrm{DW}_{\mathrm{Eq}}\right)\right)\right)
$$

269 where $\Sigma \mathrm{DW}_{\text {obs }}$ is the sum of observed biomass of the actual component in absolute terms and $270 \ln \left(\Sigma \mathrm{DW} \mathrm{Eq}_{\mathrm{Eq}}\right)$ is the sum of the unadjusted values given by the equation. The intercepts in Table 3 271 have been corrected in this way.

272 Data on the fraction of bark biomass were only available for 119 trees from nine sites. Bark 273 biomass $\left(\mathrm{DW}_{\text {bark }}\right)$ was expressed as bark proportion $(\mathrm{Bp})$ of the stem biomass $274\left(\mathrm{Bp}=\mathrm{DW}_{\mathrm{bark}} / \mathrm{DW}_{\text {stem }}\right)$ and was studied as a function of $\mathrm{DBH}$ and $\mathrm{H}$. The best correlation was 275 found with the transformed variable $1 /(\mathrm{H}+3)$. The variation in bark proportion within the stem 276 was also studied based on stem disc data. The dependent variable was then the bark proportion of 
277 the disc biomass including bark $\left(\mathrm{Bp}_{\mathrm{disc}}\right)$. The best model included a second-degree polynomial of 278 disc relative height position $\left(\mathrm{Hrel}, \mathrm{Hrel}^{2}\right)$ and the transformed variable $1 /(\mathrm{H}+3)$. The variable 279 Hrel $(\mathrm{h} / \mathrm{H}$, where $\mathrm{h}$ is height above stump) is defined in the interval $0-1$ where 0 is stump height 280 and 1 is tree top.

281 Since lodgepole pine often retains its cones for decades (Elfving et al. 2001), the cone biomass

282 can form a substantial part of the branch biomass. This amount was examined based on data

283 from 64 trees from five sites where the fresh and dry weights of cones were measured separately 284 from the branch samples. Since the appearance of cones was stochastic (several examined trees 285 lacked cones on the sample branches) a two-step model for estimation of cone biomass ( $\left.\mathrm{DW}_{\text {cone }}\right)$ 286 was formulated. In step one the probability that there are no cones (plc) was estimated with a 287 logistic regression:

$$
\left(\ln (1 / \mathrm{plc}-1)=\mathrm{b}_{0}+\mathrm{b}_{1} \cdot(\mathrm{H} /(\mathrm{DBH}+1))\right.
$$
and $b_{0}$ and $b_{1}$ are coefficients to be estimated. and OLS equations as:

(11) $\quad \mathrm{DW}_{\text {cone }}=\mathrm{DW}_{\mathrm{cl}} \times(1-\mathrm{plc})$ 
299 The estimated stem volumes according to the sectioning were used to identify outliers in the 300 data. One stem was deleted since the stem weight and the sectioned volume did not correspond.

301 Two trees were outliers from the biomass equations and it was found that their DBH-values

302 deviated more than three times the expected measurement error from the stem profile according

303 to the sectioning. The original DBH-value was then replaced with the value estimated from the 304 stem profile curve.

306 3. Results

307 Equations for estimation of total tree biomass and for the tree components: stem with bark, living

308 branches with cones, foliage and dead branches are presented in Table 3. Equations for separate

309 estimation of bark proportion and the biomass of cones are presented in Table 4 and residuals in

310 relation to observed data are shown in Figures 3-4. All independent variables included in the

311 equations were highly significant $(\mathrm{p}<0.01)$. Inspection of the residuals confirmed that they

312 fulfilled the assumptions done in the model formulation.

313

$314<$ Tables 3-4 and figures 3-4> here

316 4. Discussion 
317 The data for this study came from cultivated stands older than 20 years with top heights above 7

$318 \mathrm{~m}$. The equations are therefore not valid for younger stands. Initial growing conditions have a

319 large impact on tree shape (Lindgren et al. 2007). The sample trees represent a wide variety of

320 growing conditions. The provenances used were all from the interior of Canada between latitudes

32154 and $61^{\circ} \mathrm{N}$ and represent the provenances recommended for cultivation in northern Sweden.

322 Level 1-equations with only diameter as the independent variable had large residual variations,

323 with between-site variation as the dominant component. They are not recommended for practical

324 use but are included to demonstrate the increased efficiency of including more independent

325 variables. Inclusion of top height according to Table 3 in the model reduced the residual variance

326 substantially (calculation not shown). Stand height can be efficiently estimated by airborne laser

327 scanning (Nilsson et al. 2015) and should always be included in future large-scale biomass

328 estimations.

329 Our sampling was not focussed on a specific population of lodgepole pine. Instead we tried to

330 include stands with as many different conditions we could find regarding stands density,

331 developmental stages, site conditions etc. This means that we could expect a larger between-

332 stand residual variation than what is found in data from ordinary population sampling. For

333 example, at Örnåsen all biomass components except dead branches had lower biomass than

334 expected $(\mathrm{p}<0.01)$ and at Degerön they were all higher than expected $(\mathrm{p}<0.001)$. Also at

335 Korseleberget all components had more biomass than expected but the deviation had lower

336 significance $(\mathrm{p}=0.051)$.

337 The sampling was spread over the snow-free season, from May to October (Tab. 1), which

338 influence the foliage biomass $\left(\mathrm{DW}_{\mathrm{fol}}\right)$. If there are four fully developed age classes of needles at 
339 the peak of $\mathrm{DW}_{\text {fol }}$ in late July and three classes left when the oldest class has been shed in late

340 autumn, the summer $\mathrm{DW}_{\text {fol }}$ would be about $30 \%$ larger than the winter $\mathrm{DW}_{\text {fol. }}$. Our equations

341 probably give average values between those extremes. It should be noted that for single trees the

342 sum of predicted biomasses for different components generally deviates from the value predicted

343 by the equation for total biomass. The latter value is the best prediction of total biomass, and the

344 component sum can be brought into agreement with this value by proportional adjustment. In our

345 data the adjustment factor is in average 1.00 with the standard deviation 0.03 . This adjustment

346 method is of course approximate. Different methods for additive modelling have been proposed,

347 restricting results from the partial relations to add up to the total (Parresol 2001, Poudel and

348 Temesgen 2016, Zhao et al 2016). Our aim was however to construct flexible partial equations

349 that can be used separately for different purposes. We did not try direct additive modelling but

350 our data are enclosed and can form a basis for further development of the modelling methods.

351 Results from this study were compared with predicted biomass for lodgepole pine in Canada

352 according to Manning et al (1984) and for Scots pine in Sweden and Finland according to

353 Marklund (1988) and Repola (2009), Table 5. The Canadian study was based on data from 149

354 lodgepole pine trees in the Yukon Territory. The Marklund study was based on data from 493

355 Scots pine trees forming a representative sample from the whole of Sweden, while the Repola

356 study was based on data from 908 Scots pine trees representing both research plots and ordinary

357 forests in Finland. The comparisons were conducted for small, medium and large trees with

358 central values of diameter and height according to Table 2 as independent variables.

$360<$ Table $5>$ here 
362 The residual variation was smaller for the equations developed in this study than for the other 363 equations in the comparison (Table 5). One reason for this is probably smaller measurement

364 errors. The weighing of the whole tree used in this study gives high precision for the biomass

365 estimates. Another reason for smaller errors may be better specified partial relations.

366 In the Canadian study, residuals were given in absolute form and could not be translated to a 367 form comparable to the other studies. Instead the residuals presented here are those obtained 368 when we applied the Canadian model to our data. Living crown was split into larger branches 369 and twigs with foliage. Thus, comparable biomass components were stem with bark and living 370 tree crown. The Canadian values for dead branches refer to air-dry and not oven-dry weight.

371 For lodgepole pine, stem biomass was about $10 \%$ larger according to the Canadian model than

372 according to our equation. This may be due to a higher wood density in the naturally regenerated 373 and dense stands in the Yukon, with slow-growing trees.

374 The Yukon values for living crown biomass (in average $71.7 \mathrm{~kg}$ according to table 5) are almost 375 equal to those in our study (in average $72.2 \mathrm{~kg}$ ). For dead branches biomass the Yukon values are $37614 \%$ higher than our values. The higher Yukon values for dead branches depends probably on 377 moisture remaining in the air-dried branches. The fresh weight of dead branches was, on 378 average, $33 \%$ higher than their dry weight in our data. This relationship varied between sites in 379 the interval $15-55 \%$, probably mostly related to the weather conditions before and during 380 sampling. In conclusion, the Canadian biomass equations by Manning et al (1984) seem to give 381 comparable biomass values as our equations. 
382 The Canadian study included separate equations for stem biomass under bark and stem bark.

383 According to those equations, estimated bark proportion for the trees in Table 5 was about $20 \%$

384 higher than that estimated with the equation for bark proportion of stem dry weight in our study.

385 Cone biomass was also included in the branch biomass in the Canadian study and could not be

386 directly compared. At the five sites in our data where cones were separated they accounted for,

387 on average, $14 \%$ of the branch biomass. Average dry weight per cone was $7.5 \mathrm{~g}$.

388 For Scots pine, Marklund (1988) and Repola (2009) predict similar values for biomass of

389 different components. However, for large trees Repola (2009) predicts smaller dry weight for the

390 stem. The larger stem weight for Scots pine according to Marklund (1988) is almost the same as

391 for lodgepole pine according to this study. This looks like a coincidence, since both bark

392 thickness at breast height and probably also average wood density are larger for Scots pine than

393 for lodgepole pine. The higher wood density is because of the slower growth rate of Scots pine

394 on comparable sites, cf. Persson 1993. The most striking difference in biomass between

395 lodgepole pine and Scots pine concerns foliage and dead branches. Lodgepole pine is predicted

396 to have $50-100 \%$ higher foliage biomass than Scots pine, while the proportion of dead branches

397 of total crown biomass is almost the same for small trees $(20 \%)$, but increases to $30 \%$ in large

398 lodgepole pine and decreases to $15 \%$ in large Scots pine. Those differences are certainly

399 species-specific.

400 The stump-root system was not included in this study. According to Marklund (1988) this

401 component constituted 20-25\% of the total tree biomass for both Scots pine and Norway spruce

402 of common tree sizes $(\mathrm{DBH}=6-25 \mathrm{~cm}, \mathrm{H}=5-20 \mathrm{~m})$. In this case, the stump-root system included

403 the roots that were still attached to the stump when the tree had been pulled down. The similarity 
404 between pine and spruce in this aspect may indicate that similar values can be expected for 405 lodgepole pine.

406 Peterson and Ståhl (2006) examined the biomass of the smaller roots and found that the

407 Marklund (1988) values should be increased by $6 \%$ to include all roots down to $5 \mathrm{~mm}$ and by 11

$408 \%$ to include all roots down to $2 \mathrm{~mm}$. New functions based on an extended data-set were also

409 presented. It was found that the biomass of the stump-root systems were larger on moist than on

410 mesic and dry sites.

411 In conclusion the biomass equations presented for lodgepole pine had smaller residuals than

412 other comparable biomass equations for lodgepole pine and Scots pine, and estimated biomass in

413 different tree components deviated from these other equations as expected. The wide amplitude

414 of our data and the flexible form of our equations should make them useful for a wide range of

415 applications, both for detailed analyses at the single tree level and for large-scale estimates at the

416 stand- and forest levels.

418 Acknowledgements

419 We are grateful for assistance of the staff at the Unit for Field-based Forest Research, Swedish

420 University of Agricultural Sciences (part of SITES, Swedish Infrastructure for Ecosystem

421 Science), especially Ida Manfredsson among others for providing data and conducting the field

422 work, and Thomas Hörnlund for providing Figure 1. We are also grateful for valuable comments

423 on the manuscript by three anonymous reviewers. This study was financed by the Swedish

424 Energy Agency, Norrskogs Forskningsstiftelse, Mistra and The Future Forest Research Program.

425 We are grateful to SEES-editing Ltd. for professional linguistic revision. 


\section{References}

428 Backlund, I. and Bergsten, U. 2012. Biomass Production of dense direct seeded lodgepole pine 429 (Pinus contorta) at short rotation periods. Silva Fennica 46(4):609-623. Article id 914.

430 doi.org/10.14214/sf.914.

Brandel, G. 1990. Volymfunktioner för enskilda träd: tall, gran och björk. [Volume functions for

433 individual trees; Scots pine, Norway spruce and birch]. Swedish University of Agricultural

434 Sciences, Department of Forest Yield Research, Report 26. 183 p. ISBN 91-576-4030-0. [In

435 Swedish with English summary]

Brown. J.K. 1978. Weight and density of crowns of Rocky Mountain conifers. U.S. For. Serv.

438 Res. Pap. INT-197: 56.

439

440 Cannell, M. G. R. 1989. Physiological basis of wood production: a review. Scand. J. For. Res. 4:

441 459-490. doi:10.1080/02827588909382582.

443 Chojnacky, D. C., Heath, L. S. and Jenkins, J. C. 2014. Updated generalized biomass equations

444 for North American tree species. Forestry 87(1):129-151. doi:10.1093/forestry/cpt053. 
446 Claesson, S., Sahlén. K. and Lundmark, T. 2001. Functions for biomass estimation of young 447 Pinus sylvestris, Picea abies and Betula sp. from stands in northern Sweden with high stand 448 densities. Scand. J. For. Res. 16(2):138-146. doi:10.1080/028275801300088206.

450 Egnell, G., Jurevics, A. and Peichl, M. 2015. Negative effects of stem and stump harvest and 451 deep soil cultivation on the soil carbon and nitrogen pools are mitigated by enhanced tree 452 growth. For. Ecol. Manage. 338: 57-67. doi:10.1016/j.foreco.2014.11.006.

454 Elfving, B. 2002. Förbands- och gallringsförsök med contorta. Mätdata från 1998-2000. 455 [Spacing- and thinning experiments with lodgepole pine. Data from 1998-2000. Swedish 456 University of Agricultural Science, Department of Silviculture. Working papers 177. [in 457 Swedish].

459 Elfving, B., Ericsson, T. and Rosvall, O. 2001. The introduction of lodgepole pine for wood 460 production in Sweden - a review. For. Ecol. Manage. 141(1-2): 15-29. doi:10.1016/S0378$461 \quad \underline{1127(00) 00485-0 .}$. 
463 Ericsson, K., Huttunen, S., Nilsson. L.J. and Svenningsson, P. 2004. Bioenergy policy and 464 market development in Finland and Sweden. Energy Policy 32(15). 1707-1721.

465 doi:10.1016/S0301-4215(03)00161-7.

466

467 Gardmo, F. 2007. Uttag av energisortiment vid gallring av contorta, ett komplement till

468 konventionell gallring? [Thinning of lodgepole pine and energy harvest, a complement to

469 conventional thinning?] MSc Thesis No 14. Department of Forest Ecology and Management,

470 Swedish University of Agricultural Sciences, Umeå. 40 pp. [In Swedish].

472 Gholz, H.L, Grier, C.C., Campbell, A.G. and Brown. A.T. 1979. Equations for estimating 473 biomass and leaf area of plants in the pacific northwest. Oregon Forest Research Laboratory. 474 Pap. 41: 39. URI: http://hdl.handle.net/1957/8239.

476 Jenkins, J., Chojnacky, D. C., Heath, L. S. and Birdsay, R. A. 2003. National-scale biomass

477 estimators for United States tree species. For. Sci. 49(1):12-35.

479 Kero, I. 2007. Utbyte av massaved och biobränsle i några typbestånd av contorta. [Yield of 480 pulpwood and bioenergy in different stands of lodgepole pine]. MSc Thesis No 13. Department 481 of Forest Ecology and Management, Swedish University of Agricultural Sciences, Umeå. 21 pp. $482 \quad$ [In Swedish]. 
485 Lindgren, P. M. F., Sullivan, T. P., Sullivan, D. S., Brockley, R. P. and Winter, R. 2007.

486 Growth response of young lodgepole pine to thinning and repeated fertilization treatments: 10-

487 year results. Forestry. 80(5):587-611. doi 10.1093/forestry/cpm039.

489 Litton, C.M., Ryan, M.G., Tinker, D.B. and Knight, D.H. 2003. Belowground and aboveground 490 biomass in young postfire lodgepole pine forests of contrasting tree density. Can. J. For. Res.. 491 33(2): 351-363. doi: 10.1139/X02-181.

492

493 Long, J.N. and Smith, F.W. 1992. Volume increment in Pinus contorta var. latifolia - the 494 influence of stand development and crown dynamics. For. Ecol. and Manage. 53(1-4): 53-64. 495 doi: 10.1016/0378-1127(92)90033-6.

497 Manning, G.H., Massie, M.R.C. and Rudd, J.1984. Metric single-tree weight tables for the 498 Yukon Territory. Inf. Rep. BC-X-250. Environment Canada. Canadian Forestry Service. Pacific 499 Forest Research Centre. Victoria. BC. 60 p. 
501 Marklund, L-G. 1988. Biomassafunktioner för tall, gran och björk i Sverige. [Biomassfunctions

502 for Scots pine, Norway spruce and birch in Sweden] Swedish University of Agricultural

503 Sciences, inst. för skogstaxering. Rapport 45. [In Swedish].

505 Nilsson, M., Nordkvist, K., Jonzen, J., Axensten, P., Olsson, H., Wallerman, J., Egberth, M.,

506 Lindgren, N., Larsson, S., Nilsson, L., and Eriksson, J. 2015. A nationwide forest attribute map

507 of Sweden derived using airborne laser scanning data and field data from the national forest

508 inventory. In: Proceedings of SilviLaser 2015, 14th conference on Lidar Applications for

509 Assessing, September 28-30, 2015, La Grande Motte, France, pp. 211-213.

511 Octave, S. and Thomas, D. 2009. Biorefinery: Toward an industrial metabolism. Biochimie.

512 91(6): 659-664. doi:10.1016/j.biochi.2009.03.015.

514 Parresol, B. R. 2001. Additivity of nonlinear biomass equations. Can. J. For. Res. 31:865-878.

515 DOI:10.1139/cjfr-31-5-865.

517 Persson, A. 1993. Wood properties of Pinus contorta. In proceeding: Pinus contorta - from untamed

518 forest to domesticated crop. Meeting of IUFRO WP 2.02.06 and Frans kempe symposium, Umeå, August

519 24-28, 1992. Lindgren, D. (editor). Dept. of Forest Genetics and Plant Physiology, SLU. Report 11: 38-

520 59, 1993. ISSN 0348-7954. 
522 Peterson, H. and Ståhl, G. 2006. Functions for below-ground biomass of Pinus sylvestris, Picea

523 abies, Betula pendula and Betula pubescens in Sweden. Scand. J. For. Res. 21 (Suppl 7):84-93.

524 doi 10.1080/14004080500486864.

526 Poudel, K. P. and Temesgen H. 2016. Methods for estimating aboveground biomass and its

527 components for Douglas-fir and lodgepole pine trees. Can. J. For. Res. 46:77-87.

528 Dx.doi.org/10.1139/cjfr-2015-0256

530 Repola, J. 2008. Biomass equations for birch in Finland. Silva Fennica 42(4):605-624.

531 http://www.metla.fi/silvafennica/full/sf42/sf424605.pdf

533 Repola, J. 2009. Biomass equations for Scots pine and Norway spruce in Finland. Silva Fennica 534 43(4):625-647. http://www.metla.fi/silvafennica/full/sf43/sf4625.pdf

536 Repola, J. and Ulvcrona, K. 2014. Modelling biomass of young and dense Scots pine (Pinus

537 sylvestris L.) dominated mixed forests in northern Sweden. Silva Fennica_vol. $\underline{48}$ no. $\underline{5}$ article id $538 \quad \underline{1190}$. doi.org/10.14214/sf.1190 
542 Satoo, T. and Madgwick, H.A.I .1982. Forest Biomass (Forestry Sciences ed.). The Hague,

543 Boston, London, Martinus Nijhoff/Dr. W. Junk publishers. ISBN 90-247-2710-3.

545 Snowdon, P. 1991. A ratio estimator for bias correction in logarithmic regressions. Can. J. For.

546 Res. 21:720-724. doi: 10.1139/x91-101

548 Ter-Mikaelian, M. T. and Korzukhin, M. D. 1997. Biomass equations for sixty-five North

549 American tree species. For. Ecol. Manage. 97(1):1-24. doi:10.1016/S0378-1127(97)00019-4

551 Ulvcrona, K.A., Karlsson, L., Backlund, I. and Bergsten, U. 2013. Comparison of silvicultural 552 regimes of lodgepole pine (Pinus contorta) in Sweden 5 years after precommercial thinning. 553 Silva Fennica 47(3). id 974. doi.org/10.14214/sf.974.

555 Zhao, D., Kane, M., Teskey, R. and Markewitz, D. 2016. Modeling aboveground biomass 556 components and volume-to-weight conversion ratios for loblolly pine trees. For. Sci. 62.

557 http://dx.doi.org/10.5849/forsci.15-129 
559 Zobel, B. J. and van Buijtenen, J.P.V. 1989. Wood Variation its causes and control, in Wood

560 Variation: Its Causes and Control, Springer-Verlag, Berlin, 1989. 363 pp. ISBN 78-3-642-

$561 \quad 74071-8$

562

563 Table 1. Stand data, sample year and number of sample trees per site

\begin{tabular}{|c|c|c|c|c|c|c|c|c|}
\hline Site & $\begin{array}{l}\text { Alt. (m) } \\
\text { (a.s.l) }\end{array}$ & $\begin{array}{l}\text { Age } \\
\text { years }\end{array}$ & $\begin{array}{l}\text { Top height } \\
\text { (m) }\end{array}$ & $\begin{array}{l}\text { Number of } \\
\text { stems } h^{-1}\end{array}$ & $\begin{array}{l}\text { Basal area } \\
m^{2} h a^{-1}\end{array}$ & $\begin{array}{l}\text { Sampling } \\
\text { year- } \\
\text { month }\end{array}$ & $\begin{array}{l}\text { Number } \\
\text { of sample } \\
\text { trees }\end{array}$ & $\begin{array}{l}\text { Experim. } \\
\text { number/ } \\
\text { reference }\end{array}$ \\
\hline Örnåsen & 370 & 26 & $14-16$ & $1630-1790$ & $27-31$ & $2010-10$ & 19 & 1156 \\
\hline Långträsk & 260 & 31 & $13-14$ & $1830-2080$ & $26-28$ & $2010-10$ & 13 & 1155 \\
\hline Långsjönäset & 360 & 40 & $15-18$ & $500-6034$ & $17-51$ & 2008-05 & 29 & 1209 \\
\hline Kälvjärv & 150 & 28 & $8-9$ & $1053-1614$ & $10-14$ & $2005-10$ & 20 & Ref 1 \\
\hline Snägden & 160 & 25 & 13 & 1725 & 24 & 2006-07 & 11 & $\operatorname{Ref} 2$ \\
\hline Rödmyrdalen & 150 & 29 & 15 & 2320 & 36 & 2006-07 & 10 & $\operatorname{Ref} 2$ \\
\hline Toböle 1 & 80 & 48 & 19 & 860 & 28 & 1999-05 & 8 & Ref 3 \\
\hline Toböle 1 & 80 & 61 & 26 & 610 & 30 & 2012-09 & 4 & 1113 \\
\hline Toböle 2 & 80 & 84 & 32 & 450 & 45 & 2012-09 & 4 & 1962 \\
\hline Korseleberget & 350 & 87 & 28 & 540 & 34 & $2012-10$ & 8 & 1959 \\
\hline Tönningstenen & 440 & 29 & 9 & 3663 & 12 & 2011-09 & 2 & $\operatorname{Ref} 4$ \\
\hline Framsängsån & 230 & 29 & 13 & 2338 & 29 & 2011-09 & 2 & Ref 4 \\
\hline Bjärkliden & 325 & 20 & 8 & 5000 & 21 & 2012-09 & 18 & Ref 5 \\
\hline Degerön & 150 & 27 & $10-12$ & 2500 & $16-22$ & 2012-09 & 16 & $\operatorname{Ref} 6$ \\
\hline
\end{tabular}

564

565 Note. Experiment numbers refer to the Swedish database Silva Boreal (2014) for forest field

566 experiments. References: ref 1: Kero 2007; ref 2: Gardmo 2007; ref 3: Elfving 2002; ref 4:

567 Backlund and Bergsten 2012; ref 5: Ulvcrona et al. 2013; ref 6: Egnell et al. 2015. 
574 Table 2. Distribution of biomass sample trees in the different height- and diameter classes.

575 Number of sample trees in each class.

\begin{tabular}{|c|c|c|c|c|c|c|c|c|c|c|c|c|c|c|c|c|c|}
\hline H-clas & & & & & & $D B 1$ & clas & $\mathrm{cm}$ & & & & & & & & & \\
\hline $\mathrm{m}$ & $4-6$ & -8 & -10 & -12 & -14 & -16 & -18 & -20 & -22 & -24 & -26 & -28 & -30 & -32 & -34 & -36 & Total \\
\hline $4-6$ & 1 & 2 & & & & & & & & & & & & & & & 3 \\
\hline-8 & & 10 & 8 & 6 & 1 & & & & & & & & & & & & 25 \\
\hline-10 & 1 & 4 & 3 & 12 & 4 & 1 & & & & & & & & & & & 25 \\
\hline-12 & & 3 & 5 & 6 & 4 & 5 & 1 & & & & & & & & & & 24 \\
\hline-14 & & 2 & 2 & 2 & 4 & 9 & 4 & 4 & & & & & & & & & 27 \\
\hline-16 & & & 1 & 4 & 7 & 2 & 7 & 4 & 1 & 2 & & & & & & & 28 \\
\hline-18 & & & & & 2 & 3 & 1 & 3 & & 1 & & & & & & & 10 \\
\hline-20 & & & & & 1 & 1 & & 1 & 2 & & & & & & & & 5 \\
\hline-22 & & & & & & & & 1 & 2 & & & & & & & & 3 \\
\hline-24 & & & & & & & & & 3 & & & 2 & & & 1 & & 6 \\
\hline-26 & & & & & & & & & & & 1 & & 2 & 1 & & & 4 \\
\hline-28 & & & & & & & & & & & & & & & 1 & & 1 \\
\hline-30 & & & & & & & & & & & 1 & & & 1 & & 1 & 3 \\
\hline Total & 2 & 21 & 19 & 30 & 23 & 22 & 13 & 13 & 8 & 3 & 2 & 2 & 2 & 2 & 2 & 1 & 164 \\
\hline
\end{tabular}

576

577

578

579

580

581

582

583 
585 Table 3. Biomass equations for lodgepole pine, giving the dry weight (DW, $\mathrm{kg}$ ) of different 586 components as a function of DBH over bark $(\mathrm{DBH}, \mathrm{cm})$, total tree height $(\mathrm{H}, \mathrm{m})$ and length of 587 living crown $(\mathrm{crl}, \mathrm{m})$. The terms $\mathrm{s}^{2}$ sites and $\mathrm{s}^{2}$ trees denotes the residual variances between and 588 within sites, and Sres-tot $=\sqrt{ }\left(\mathrm{s}^{2}\right.$ sites $+\mathrm{s}^{2}$ trees $)$ is the total residual error of the equation. Standard 589 errors of the coefficients are given in parenthesis below the coefficients

\begin{tabular}{|c|c|c|c|c|c|c|c|c|c|}
\hline \multicolumn{10}{|c|}{ Coefficients for independent variables } \\
\hline $\begin{array}{l}\text { Dependent } \\
\text { variable }\end{array}$ & Intercept $^{1}$ & $\ln (\mathrm{DBH})$ & $\ln (\mathrm{H})$ & $\ln (\mathrm{H}-1.3)$ & $\mathrm{H} / \mathrm{DBH}$ & $\ln (\mathrm{crl})$ & $\mathrm{s}^{2}$ sites & $\mathrm{s}^{2}$ trees & Sres-tot \\
\hline \multirow[t]{2}{*}{$\begin{array}{l}\text { All above stump: } \\
\ln \left(\mathrm{DW}_{\text {tot }}\right)\end{array}$} & $\begin{array}{l}-2.177 \\
(0.089)\end{array}$ & $\begin{array}{c}2.371 \\
(0.028)\end{array}$ & & & & & 0.0320 & 0.0097 & 0.204 \\
\hline & $\begin{array}{l}-3.958 \\
(0.336)\end{array}$ & $\begin{array}{c}2.182 \\
(0.033)\end{array}$ & $\begin{array}{c}2.852 \\
(0.840)\end{array}$ & $\begin{array}{l}-2.062 \\
(0.744)\end{array}$ & & & 0.0025 & 0.0075 & 0.100 \\
\hline \multirow[t]{2}{*}{$\begin{array}{l}\text { Stem with bark: } \\
\ln \left(D_{\text {stem }}\right)\end{array}$} & $\begin{array}{l}-1.834 \\
(0.138)\end{array}$ & $\begin{array}{c}2.121 \\
(0.035)\end{array}$ & & & & & 0.1379 & 0.0154 & 0.392 \\
\hline & $\begin{array}{l}-5.235 \\
(0.281)\end{array}$ & $\begin{array}{c}1.729 \\
(0.026)\end{array}$ & $\begin{array}{l}4.832 \\
(0.690)\end{array}$ & $\begin{array}{l}-3.265 \\
(0.610)\end{array}$ & & & 0.0024 & 0.0045 & 0.083 \\
\hline \multirow[t]{3}{*}{$\begin{array}{l}\text { Living branches: } \\
\ln \left(\mathrm{DW}_{\mathrm{lbr}}\right)\end{array}$} & $\begin{array}{l}-7.665 \\
(0.293)\end{array}$ & $\begin{array}{l}3.601 \\
(0.093)\end{array}$ & & & & & 0.3143 & 0.1108 & 0.652 \\
\hline & $\begin{array}{l}-4.619 \\
(0.216)\end{array}$ & $\begin{array}{l}4.269 \\
(0.113)\end{array}$ & $\begin{array}{l}-1.858 \\
(0.141)\end{array}$ & & & & 0.0086 & 0.0939 & 0.320 \\
\hline & $\begin{array}{l}-4.655 \\
(0.208)\end{array}$ & $\begin{array}{c}3.657 \\
(0.133)\end{array}$ & $\begin{array}{l}-1.967 \\
(0.132)\end{array}$ & & & $\begin{array}{c}0.940 \\
(0.136)\end{array}$ & 0.0103 & 0.0718 & 0.287 \\
\hline \multirow[t]{3}{*}{$\begin{array}{l}\text { Foliage } \\
\ln \left(\mathrm{DW}_{\text {fol }}\right)\end{array}$} & $\begin{array}{l}-5.642 \\
(0.272)\end{array}$ & $\begin{array}{c}2.717 \\
(0.085)\end{array}$ & & & & & 0.3951 & 0.0912 & 0.697 \\
\hline & $\begin{array}{l}-1.708 \\
(0.441)\end{array}$ & $\begin{array}{c}1.759 \\
(0.114)\end{array}$ & & & $\begin{array}{l}-1.432 \\
(0.168)\end{array}$ & & 0.0368 & 0.0839 & 0.348 \\
\hline & $\begin{array}{l}-1.577 \\
(0.404)\end{array}$ & $\begin{array}{l}1.101 \\
(0.149)\end{array}$ & & & $\begin{array}{l}-1.547 \\
(0.154)\end{array}$ & $\begin{array}{c}0.834 \\
(0.134)\end{array}$ & 0.0322 & 0.0677 & 0.316 \\
\hline \multirow[t]{2}{*}{$\begin{array}{l}\text { Dead branches: } \\
\ln \left(\mathrm{DW}_{\mathrm{dbr}}\right)\end{array}$} & $\begin{array}{l}-6.235 \\
(0.349)\end{array}$ & $\begin{array}{l}2.797 \\
(0.120)\end{array}$ & & & & & 0.2321 & 0.1963 & 0.655 \\
\hline & --6.052 & 3.609 & & & & -1.138 & 0.163 & 0.171 & 0.577 \\
\hline
\end{tabular}




$(0.320) \quad(0.188)$

${ }^{1}$ Corrected for logarithmic bias

594 Table 4. Equations for bark proportion of stem biomass and for cone biomass. $\mathrm{H}$ is the tree 595 height (m), $\mathrm{H}_{\text {rel }}$ is relative height ( $\mathrm{stump}=0$, top=1), $\mathrm{DW}_{\mathrm{cl}}$ is dry weight of cones in branch 596 samples with cones, plc is the probability of cones being absent from the branch sample

\begin{tabular}{|c|c|c|c|c|c|c|c|c|c|}
\hline \multirow{2}{*}{$\begin{array}{l}\text { Dependent } \\
\text { variable }\end{array}$} & \multicolumn{6}{|c|}{ Coefficients } & & & \\
\hline & Intercept & $1 /(\mathrm{H}+3)$ & Hrel & $(\mathrm{Hrel})^{2}$ & $\ln (\mathrm{H})$ & $\mathrm{H} /(\mathrm{DBH}+1)$ & $\begin{array}{l}\text { Adj. } \\
\mathrm{R}^{2}\end{array}$ & $\mathrm{~S}_{\mathrm{res}}$ & $\mathrm{n}$ \\
\hline $\begin{array}{l}\text { Bark prop. } \\
\text { of DW } \\
\text { stem }\end{array}$ & 0.0524 & 0.5073 & & & & & 0.437 & 0.0109 & 119 \\
\hline $\begin{array}{l}\text { Bark prp. of } \\
\text { DW }_{\text {disc }}\end{array}$ & 0.0418 & 0.7275 & -0.1222 & 0.2350 & & & 0.722 & 0.0192 & 714 \\
\hline $\ln \left(\mathrm{DW}_{\mathrm{c} 1}\right)$ & -0.1128 & & & & 2.2768 & -7.1103 & 0.610 & 1.087 & 54 \\
\hline $\ln (1 /$ plc-1) & 14.63 & & & & & -12.82 & & & 64 \\
\hline
\end{tabular}


608 Table 5. Estimated biomass ( $\mathrm{kg}$ per tree) of different tree components of three tree sizes

609 according to equations from this study and from other studies. Figures in italics indicate residual

610 standard deviation of the different equations

\begin{tabular}{|c|c|c|c|c|c|c|c|c|c|c|c|}
\hline \multicolumn{2}{|c|}{ Tree variables } & \multicolumn{5}{|c|}{ Biomass component } & \multicolumn{5}{|c|}{ Biomass component } \\
\hline $\begin{array}{l}\text { DBH } \\
(\mathrm{cm})\end{array}$ & $\begin{array}{c}\mathrm{H} \\
(\mathrm{m})\end{array}$ & $\mathrm{DW}_{\text {stem }}$ & $\overline{\mathrm{DW}_{\mathrm{lbr}}}$ & $\overline{\mathrm{DW}_{\text {fol }}}$ & $\overline{\mathrm{DW}_{\mathrm{dbr}}}$ & $\mathrm{DW}_{\text {tot }}$ & $\mathrm{DW}_{\text {stem }}$ & $\mathrm{DW}_{\mathrm{lbr}}$ & $\mathrm{DW}_{\text {fol }}$ & $\mathrm{DW}_{\mathrm{dbr}}$ & $\mathrm{DW}_{\text {tot }}$ \\
\hline & & \multicolumn{5}{|c|}{ lodgepole pine-this study } & \multicolumn{5}{|c|}{ Scots pine-Marklund 1988} \\
\hline $\mathrm{S}_{\mathrm{res}}$ & & 0.083 & 0.320 & 0.348 & 0.655 & 0.100 & 0.196 & 0.456 & 0.527 & 0.945 & - \\
\hline 7 & 9 & 8.0 & 0.7 & 0.9 & 0.5 & 10.4 & 7.8 & 1.4 & 0.6 & 0.4 & 10.2 \\
\hline 15 & 15 & 53.8 & 6.8 & 5.0 & 3.8 & 72.0 & 54.6 & 9.6 & 3.2 & 2.0 & 69.4 \\
\hline \multirow[t]{2}{*}{30} & 25 & 351.5 & 50.4 & 22.5 & 26.6 & 452.5 & 340.7 & 38.8 & 10.3 & 6.4 & 396.2 \\
\hline & & \multicolumn{5}{|c|}{ lodgepole pine-Manning et al 1984} & \multicolumn{5}{|c|}{ Scots pine-Repola 2009} \\
\hline $\mathrm{S}_{\text {res }}$ & & $(0.10)^{1}$ & $(0.70)$ & $(0.60)$ & $(0.59)$ & $(0.14)^{I}$ & 0.110 & 0.361 & 0.476 & 0.784 & 0.138 \\
\hline 7 & 9 & 8.5 & 1.0 & 1.7 & 0.3 & 11.5 & 8.2 & 0.9 & 0.6 & 0.4 & 10.2 \\
\hline 15 & 15 & 59.0 & 6.0 & 5.9 & 4.6 & 75.6 & 55.4 & 6.9 & 3.3 & 2.2 & 69.4 \\
\hline 30 & 25 & 388.2 & 38.7 & 33.0 & 33.1 & 493.1 & 309.7 & 37.8 & 11.4 & 10.2 & 374.3 \\
\hline
\end{tabular}

611

$612{ }^{1}$ Values in parentheses are residuals when the Manning model is used with our data, that is use

613 of $\mathrm{D}^{2} \mathrm{H}$ as the only independent variable for all components with OLS on our data.

614

615

616

617

618

619

620

621

622

623

624 
625 Figure legends

626 Figure 1. Map showing location of all sites for biomass sampling. Latitude and longitude are 627 given in degrees, minutes and seconds (WGS84).

628

629

Figure 2. The sampling procedure. In the field the raw weight was determined for 6 discs, 6 stem

630 sections (between discs), 4 living sample branches (one per strata), 4 living branch strata, 1 dead

631 sample branch, 1 dead-branch bunch. Discs and sample branches were brought to the lab for

632 drying and dry weight determination.

634 Figure 3. Observed and estimated bark proportion of stem biomass according to equations in

635 Table 4: in total for stems of different heights (upper diagram) and in stem discs at different 636 levels in the stem (lower diagram). Figure 4. Observed and estimated cone biomass per tree according to the equations in Table 4.

639 Points mark mean observed values in different classes and figures are number of observations in 640 that class. The dashed line is the reference (regression). 


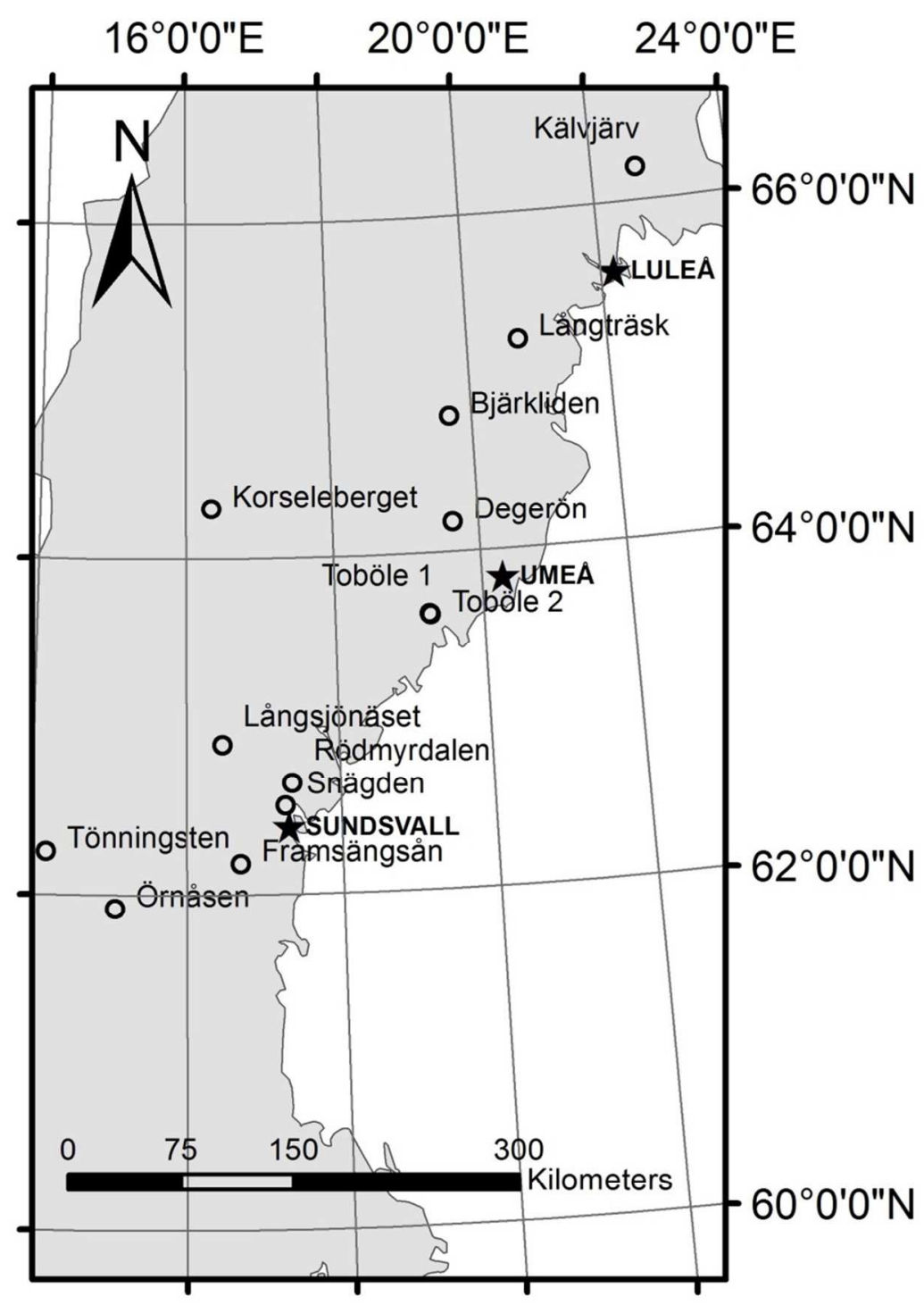

647 Figure 1. Map showing location of all sites for biomass sampling. Latitude and longitude are 648 given in degrees, minutes and seconds (WGS84). 


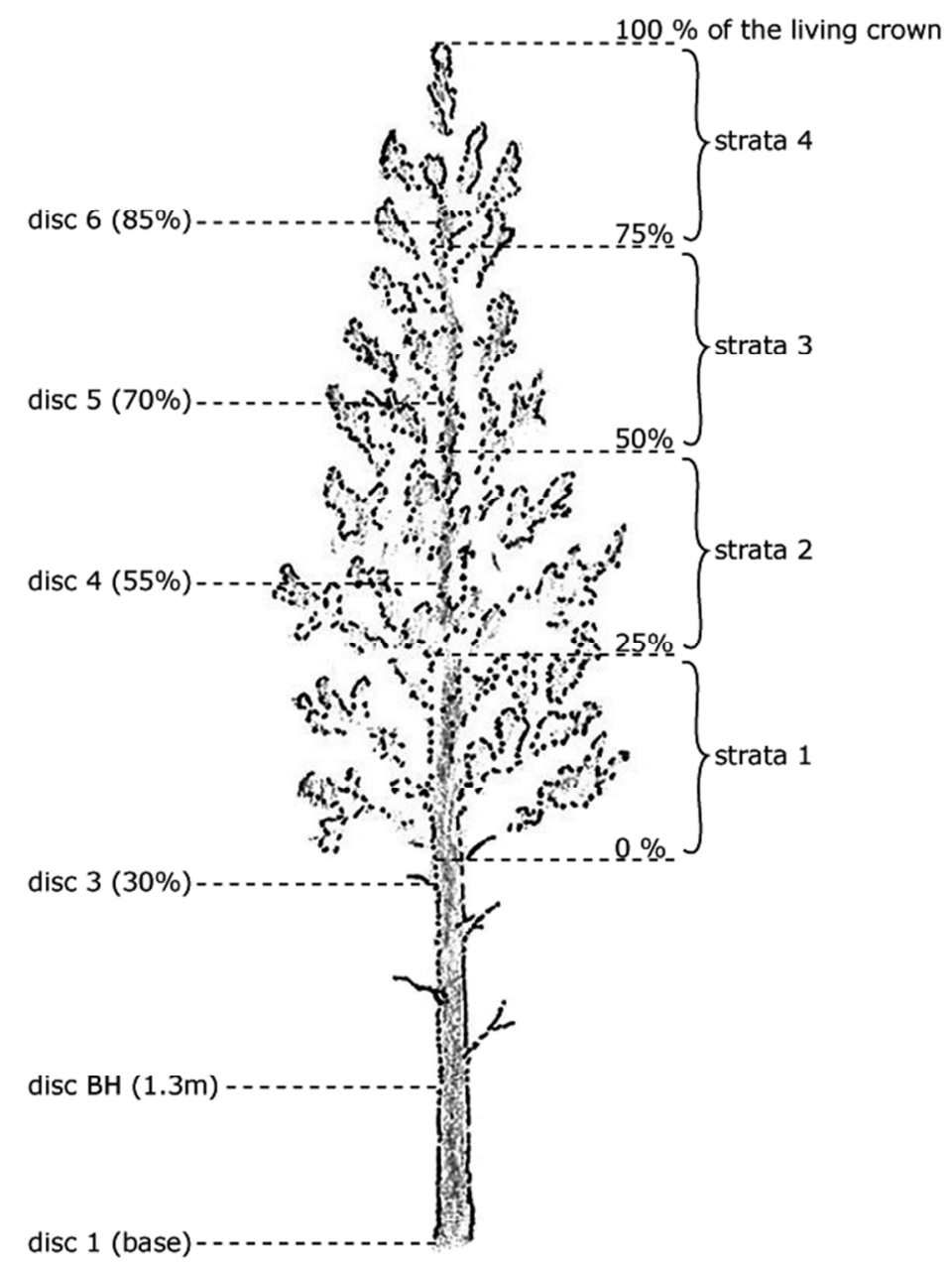

651

652 Figure 2. The sampling procedure. In the field the raw weight was determined for 6 discs, 6 653 stem sections (between discs), 4 living sample branches (one per strata), 4 living branch strata, 1 654 dead sample branch, 1 dead-branch bunch. Discs and sample branches were brought to the lab 655 for drying and dry weight determination.

656

657

658

659 


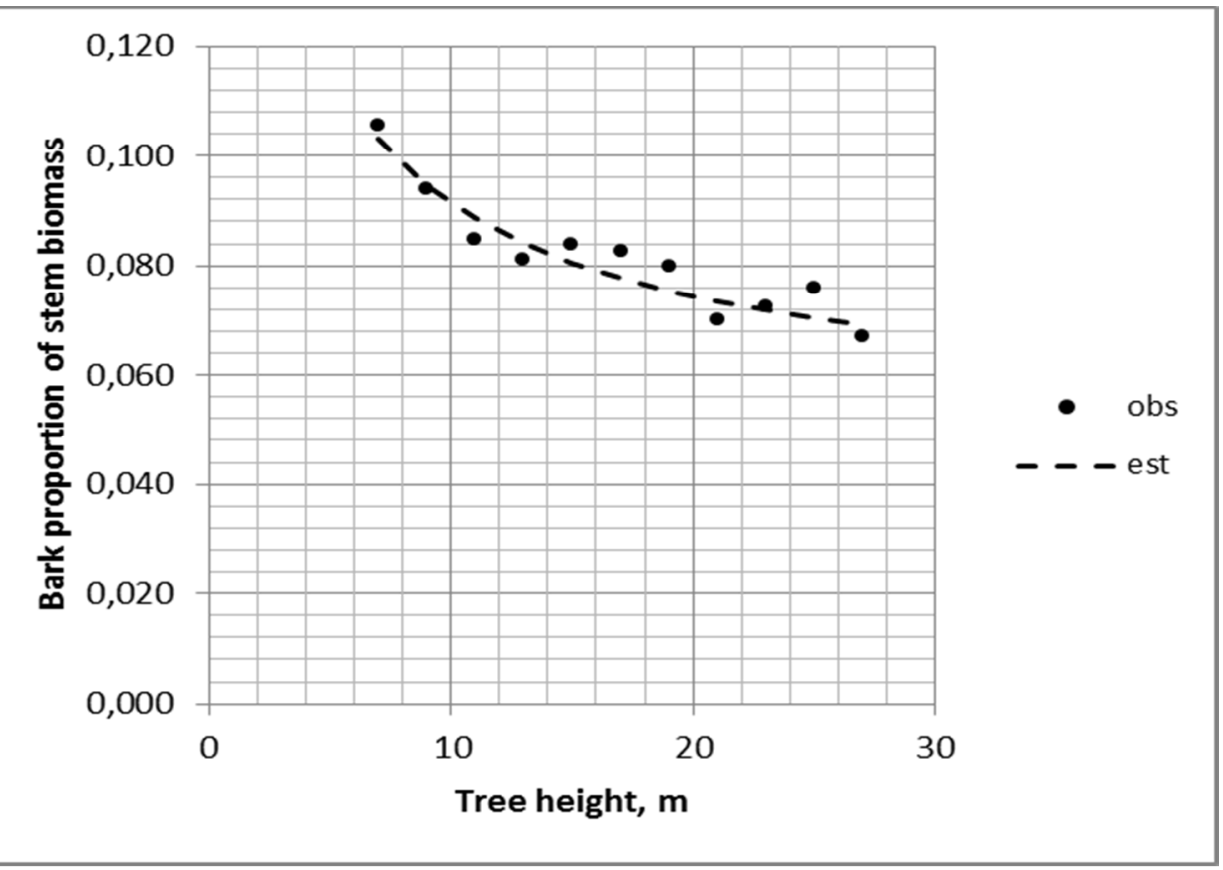

661

662

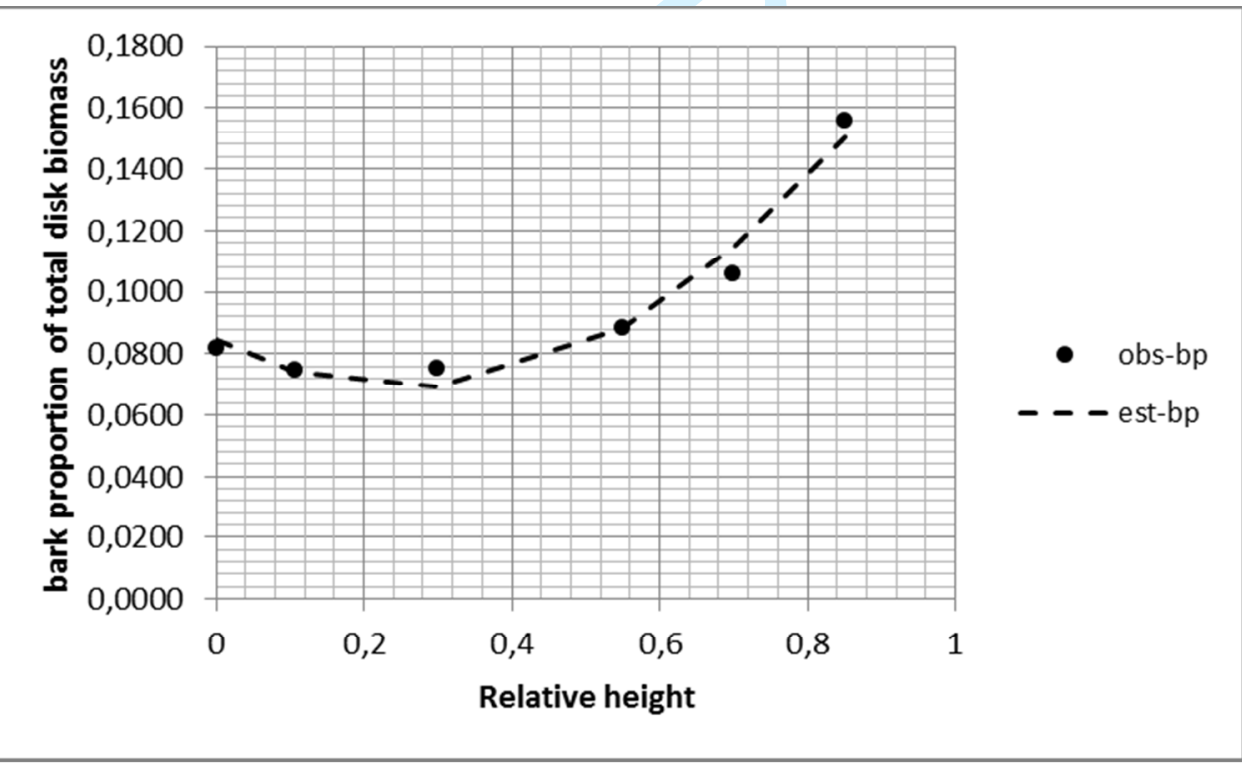

663

664 Figure 3. Observed and estimated bark proportion of stem biomass according to equations in

665 Table 4: in total for stems of different height (upper diagram) and in stem discs at different 666 levels in the stem (lower diagram). 


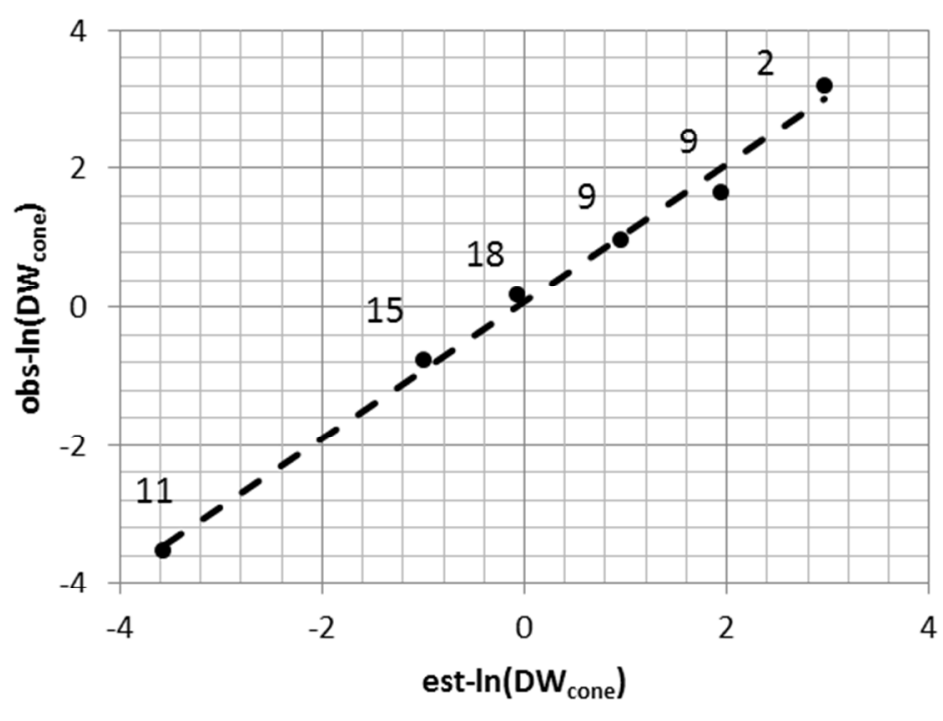

674 Figure 4. Observed and estimated cone biomass per tree according to equations in Table 4.

675 Points mark mean observed values in different classes and figures are number of observations in 676 that class. The dashed line is the reference (regression). 
Table 1. Stand data, sample year and number of sample trees per site

\begin{tabular}{lllllllll}
\hline Site & Alt. $(m)$ & Age & Top height & $\begin{array}{l}\text { Number of } \\
\text { stems } \mathrm{ha}^{-1}\end{array}$ & $\begin{array}{l}\text { Basal area } \\
\mathrm{m}^{2} \mathrm{ha}^{-1}\end{array}$ & $\begin{array}{l}\text { Sampling } \\
\text { year- } \\
\text { month }\end{array}$ & $\begin{array}{l}\text { Number } \\
\text { of sample } \\
\text { trees }\end{array}$ & $\begin{array}{l}\text { Experim. } \\
\text { number/ } \\
\text { reference }\end{array}$ \\
\hline Örnåsen & 370 & 26 & $14-16$ & $1630-1790$ & $27-31$ & $2010-10$ & 19 & 1156 \\
Långträsk & 260 & 31 & $13-14$ & $1830-2080$ & $26-28$ & $2010-10$ & 13 & 1155 \\
Långsjönäset & 360 & 40 & $15-18$ & $500-6034$ & $17-51$ & $2008-05$ & 29 & 1209 \\
Kälvjärv & 150 & 28 & $8-9$ & $1053-1614$ & $10-14$ & $2005-10$ & 20 & Ref 1 \\
Snägden & 160 & 25 & 13 & 1725 & 24 & $2006-07$ & 11 & Ref 2 \\
Rödmyrdalen & 150 & 29 & 15 & 2320 & 36 & $2006-07$ & 10 & Ref 2 \\
Toböle 1 & 80 & 48 & 19 & 860 & 28 & $1999-05$ & 8 & Ref 3 \\
Toböle 1 & 80 & 61 & 26 & 610 & 30 & $2012-09$ & 4 & 1113 \\
Toböle 2 & 80 & 84 & 32 & 450 & 45 & $2012-09$ & 4 & 1962 \\
Korseleberget & 350 & 87 & 28 & 540 & 34 & $2012-10$ & 8 & 1959 \\
Tönningstenen & 440 & 29 & 9 & 3663 & 12 & $2011-09$ & 2 & Ref 4 \\
Framsängsån & 230 & 29 & 13 & 2338 & 29 & $2011-09$ & 2 & Ref 4 \\
Bjärkliden & 325 & 20 & 8 & 5000 & 21 & $2012-09$ & 18 & Ref 5 \\
Degerön & 150 & 27 & $10-12$ & 2500 & $16-22$ & $2012-09$ & 16 & Ref 6 \\
\hline
\end{tabular}

Note. Experiment numbers refer to the Swedish database Silva Boreal (2014) for forest field experiments. References: ref 1: Kero 2007; ref 2: Gardmo 2007; ref 3: Elfving 2002; ref 4: Backlund and Bergsten 2012; ref 5: Ulvcrona et al. 2013; ref 6: Egnell et al. 2015. 
Table 2. Distribution of biomass sample trees in the different height- and diameter classes. Number of sample trees in each class.

\begin{tabular}{|c|c|c|c|c|c|c|c|c|c|c|c|c|c|c|c|c|c|}
\hline H-class & & & & & & $D B I$ & clas & $\mathrm{cm}$ & & & & & & & & & \\
\hline $\mathrm{m}$ & $4-6$ & -8 & -10 & -12 & -14 & -16 & -18 & -20 & -22 & -24 & -26 & -28 & -30 & -32 & -34 & -36 & Total \\
\hline $4-6$ & 1 & 2 & & & & & & & & & & & & & & & 3 \\
\hline-8 & & 10 & 8 & 6 & 1 & & & & & & & & & & & & 25 \\
\hline-10 & 1 & 4 & 3 & 12 & 4 & 1 & & & & & & & & & & & 25 \\
\hline-12 & & 3 & 5 & 6 & 4 & 5 & 1 & & & & & & & & & & 24 \\
\hline-14 & & 2 & 2 & 2 & 4 & 9 & 4 & 4 & & & & & & & & & 27 \\
\hline-16 & & & 1 & 4 & 7 & 2 & 7 & 4 & 1 & 2 & & & & & & & 28 \\
\hline-18 & & & & & 2 & 3 & 1 & 3 & & 1 & & & & & & & 10 \\
\hline-20 & & & & & 1 & 1 & & 1 & 2 & & & & & & & & 5 \\
\hline-22 & & & & & & & & 1 & 2 & & & & & & & & 3 \\
\hline-24 & & & & & & & & & 3 & & & 2 & & & 1 & & 6 \\
\hline-26 & & & & & & & & & & & 1 & & 2 & 1 & & & 4 \\
\hline-28 & & & & & & & & & & & & & & & 1 & & 1 \\
\hline-30 & & & & & & & & & & & 1 & & & 1 & & 1 & 3 \\
\hline Total & 2 & 21 & 19 & 30 & 23 & 22 & 13 & 13 & 8 & 3 & 2 & 2 & 2 & 2 & 2 & 1 & 164 \\
\hline
\end{tabular}


Table 3. Biomass equations for lodgepole pine, giving the dry weight (DW, $\mathrm{kg}$ ) of different components as a function of DBH over bark $(\mathrm{DBH}, \mathrm{cm})$, total tree height $(\mathrm{H}, \mathrm{m})$ and length of living crown $(\mathrm{crl}, \mathrm{m})$. The terms $\mathrm{s}^{2}$ sites and $\mathrm{s}^{2}$ trees denotes the residual variances between and within sites, and Sres-tot $=\sqrt{ }\left(s^{2}\right.$ sites $+s^{2}$ trees $)$ is the total residual error of the equation. Standard errors of the coefficients are given in parenthesis below the coefficients

\begin{tabular}{|c|c|c|c|c|c|c|c|c|c|}
\hline \multicolumn{10}{|c|}{ Coefficients for independent variables } \\
\hline $\begin{array}{l}\text { Dependent } \\
\text { variable }\end{array}$ & Intercept $^{1}$ & $\ln (\mathrm{DBH})$ & $\ln (\mathrm{H})$ & $\ln (\mathrm{H}-1.3)$ & $\mathrm{H} / \mathrm{DBH}$ & $\ln (\mathrm{crl})$ & $\mathrm{s}^{2}$ sites & $\mathrm{s}^{2}$ trees & $\begin{array}{l}\text { Sres- } \\
\text { tot }\end{array}$ \\
\hline \multirow[t]{2}{*}{$\begin{array}{l}\text { All above stump: } \\
\ln \left(\mathrm{DW}_{\text {tot }}\right)\end{array}$} & $\begin{array}{l}-2.177 \\
(0.089)\end{array}$ & $\begin{array}{c}2.371 \\
(0.028)\end{array}$ & & & & & 0.0320 & 0.0097 & 0.204 \\
\hline & $\begin{array}{l}-3.958 \\
(0.336)\end{array}$ & $\begin{array}{c}2.182 \\
(0.033)\end{array}$ & $\begin{array}{c}2.852 \\
(0.840)\end{array}$ & $\begin{array}{l}-2.062 \\
(0.744)\end{array}$ & & & 0.0025 & 0.0075 & 0.100 \\
\hline \multirow[t]{2}{*}{$\begin{array}{l}\text { Stem with bark: } \\
\ln \left(\mathrm{DW}_{\text {stem }}\right)\end{array}$} & $\begin{array}{l}-1.834 \\
(0.138)\end{array}$ & $\begin{array}{c}2.121 \\
(0.035)\end{array}$ & & & & & 0.1379 & 0.0154 & 0.392 \\
\hline & $\begin{array}{l}-5.235 \\
(0.281)\end{array}$ & $\begin{array}{c}1.729 \\
(0.026)\end{array}$ & $\begin{array}{c}4.832 \\
(0.690)\end{array}$ & $\begin{array}{l}-3.265 \\
(0.610)\end{array}$ & & & 0.0024 & 0.0045 & 0.083 \\
\hline \multirow[t]{3}{*}{$\begin{array}{l}\text { Living branches: } \\
\ln \left(\mathrm{DW}_{\mathrm{lbr}}\right)\end{array}$} & $\begin{array}{l}-7.665 \\
(0.293)\end{array}$ & $\begin{array}{c}3.601 \\
(0.093)\end{array}$ & & & & & 0.3143 & 0.1108 & 0.652 \\
\hline & $\begin{array}{l}-4.619 \\
(0.216)\end{array}$ & $\begin{array}{c}4.269 \\
(0.113)\end{array}$ & $\begin{array}{l}-1.858 \\
(0.141)\end{array}$ & & & & 0.0086 & 0.0939 & 0.320 \\
\hline & $\begin{array}{l}-4.655 \\
(0.208)\end{array}$ & $\begin{array}{c}3.657 \\
(0.133)\end{array}$ & $\begin{array}{l}-1.967 \\
(0.132)\end{array}$ & & & $\begin{array}{c}0.940 \\
(0.136)\end{array}$ & 0.0103 & 0.0718 & 0.287 \\
\hline \multirow[t]{3}{*}{$\begin{array}{l}\text { Foliage } \\
\ln \left(\mathrm{DW}_{\mathrm{fol}}\right)\end{array}$} & $\begin{array}{l}-5.642 \\
(0.272)\end{array}$ & $\begin{array}{c}2.717 \\
(0.085)\end{array}$ & & & & & 0.3951 & 0.0912 & 0.697 \\
\hline & $\begin{array}{l}-1.708 \\
(0.441)\end{array}$ & $\begin{array}{c}1.759 \\
(0.114)\end{array}$ & & & $\begin{array}{l}-1.432 \\
(0.168)\end{array}$ & & 0.0368 & 0.0839 & 0.348 \\
\hline & $\begin{array}{l}-1.577 \\
(0.404)\end{array}$ & $\begin{array}{c}1.101 \\
(0.149)\end{array}$ & & & $\begin{array}{l}-1.547 \\
(0.154)\end{array}$ & $\begin{array}{c}0.834 \\
(0.134)\end{array}$ & 0.0322 & 0.0677 & 0.316 \\
\hline \multirow[t]{2}{*}{$\begin{array}{l}\text { Dead branches: } \\
\ln \left(D_{\mathrm{dbr}}\right)\end{array}$} & $\begin{array}{l}-6.235 \\
(0.349)\end{array}$ & $\begin{array}{c}2.797 \\
(0.120)\end{array}$ & & & & & 0.2321 & 0.1963 & 0.655 \\
\hline & $\begin{array}{l}--6.052 \\
(0.320)\end{array}$ & $\begin{array}{c}3.609 \\
(0.188)\end{array}$ & & & & $\begin{array}{c}-1.138 \\
(0.213)\end{array}$ & 0.163 & 0.171 & 0.577 \\
\hline
\end{tabular}

\footnotetext{
${ }^{1}$ Corrected for logarithmic bias
} 
Table 4. Equations for bark proportion of stem biomass and for cone biomass. $\mathrm{H}$ is the tree height $(\mathrm{m}), \mathrm{H}_{\text {rel }}$ is relative height ( $\left(\mathrm{tump}=0\right.$, top=1), $\mathrm{DW}_{\mathrm{cl}}$ is dry weight of cones in branch samples with cones, plc is the probability of cones being absent from the branch sample

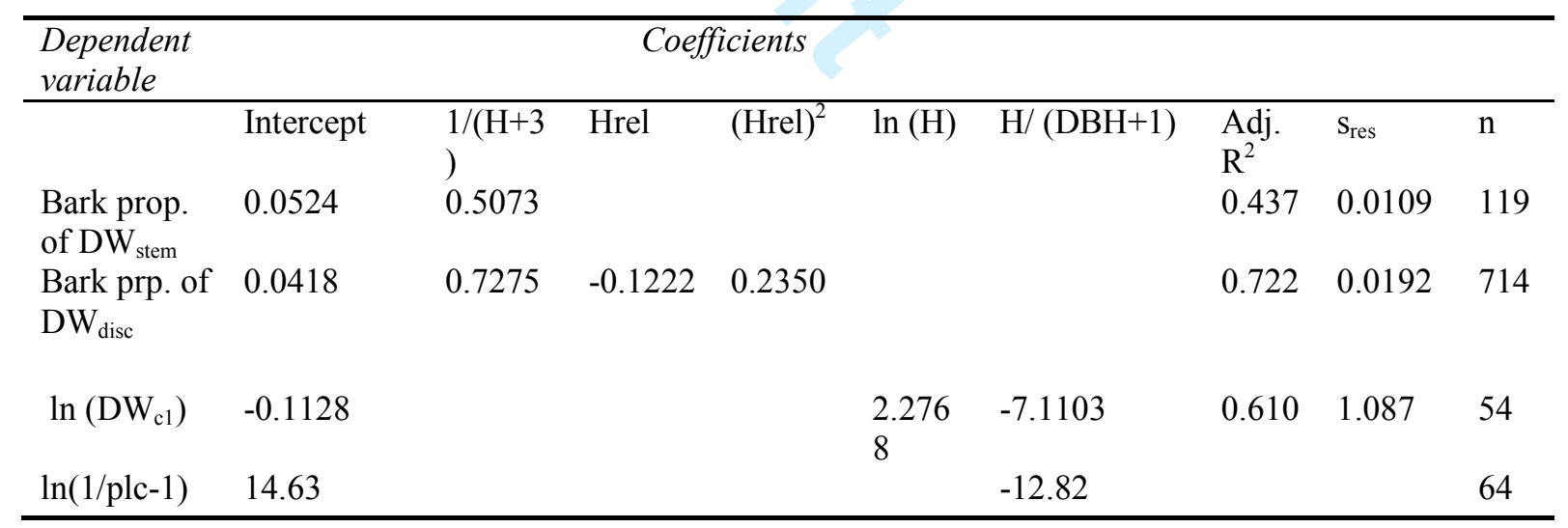


Table 5. Estimated biomass ( $\mathrm{kg}$ per tree) of different tree components of three tree sizes according to equations from this study and from other studies. Figures in italics indicate residual standard deviation of the different equations

\begin{tabular}{|c|c|c|c|c|c|c|c|c|c|c|c|}
\hline \multicolumn{2}{|c|}{ Tree variables } & \multicolumn{5}{|c|}{ Biomass component } & \multicolumn{5}{|c|}{ Biomass component } \\
\hline $\begin{array}{l}\mathrm{DBH} \\
(\mathrm{cm})\end{array}$ & $\begin{array}{c}\mathrm{H} \\
(\mathrm{m})\end{array}$ & $\mathrm{DW}_{\text {stem }}$ & $\mathrm{DW}_{\mathrm{lbr}}$ & $\mathrm{DW}_{\text {fol }}$ & $\mathrm{DW}_{\mathrm{dbr}}$ & $\mathrm{DW}_{\text {tot }}$ & $\mathrm{DW}_{\text {stem }}$ & $\mathrm{DW}_{\mathrm{lbr}}$ & $\mathrm{DW}_{\text {fol }}$ & $\mathrm{DW}_{\mathrm{dbr}}$ & $\mathrm{DW}_{\text {tot }}$ \\
\hline & & \multicolumn{5}{|c|}{ lodgepole pine-this study } & \multicolumn{5}{|c|}{ Scots pine-Marklund 1988} \\
\hline $\mathrm{S}_{\mathrm{res}}$ & & 0.083 & 0.316 & 0.348 & 0.629 & 0.100 & 0.196 & 0.456 & 0.527 & 0.945 & - \\
\hline 7 & 9 & 8.0 & 0.7 & 0.9 & 0.5 & 10.4 & 7.8 & 1.4 & 0.6 & 0.4 & 10.2 \\
\hline 15 & 15 & 53.8 & 6.8 & 5.0 & 3.8 & 72.0 & 54.6 & 9.6 & 3.2 & 2.0 & 69.4 \\
\hline \multirow[t]{2}{*}{30} & 25 & 351.5 & 50.4 & 22.5 & 26.6 & 452.5 & 340.7 & 38.8 & 10.3 & 6.4 & 396.2 \\
\hline & & \multicolumn{5}{|c|}{ lodgepole pine-Manning et al 1984} & \multicolumn{5}{|c|}{ Scots pine-Repola 2009} \\
\hline$S_{\text {res }}$ & & $(0.10)^{l}$ & $(0.70)$ & $(0.60)$ & $(0.61)$ & $(0.14)^{l}$ & 0.110 & 0.361 & 0.476 & 0.784 & 0.138 \\
\hline 7 & 9 & 8.5 & 1.0 & 1.7 & 0.3 & 11.5 & 8.2 & 0.9 & 0.6 & 0.4 & 10.2 \\
\hline 15 & 15 & 59.0 & 6.0 & 5.9 & 4.6 & 75.6 & 55.4 & 6.9 & 3.3 & 2.2 & 69.4 \\
\hline 30 & 25 & 388.2 & 38.7 & 33.0 & 33.1 & 493.1 & 309.7 & 37.8 & 11.4 & 10.2 & 374.3 \\
\hline
\end{tabular}

${ }^{1}$ Values in parentheses are residuals when the Manning model is used with our data, that is use of $\mathrm{D}^{2} \mathrm{H}$ as the only independent variable for all components with OLS on our data 


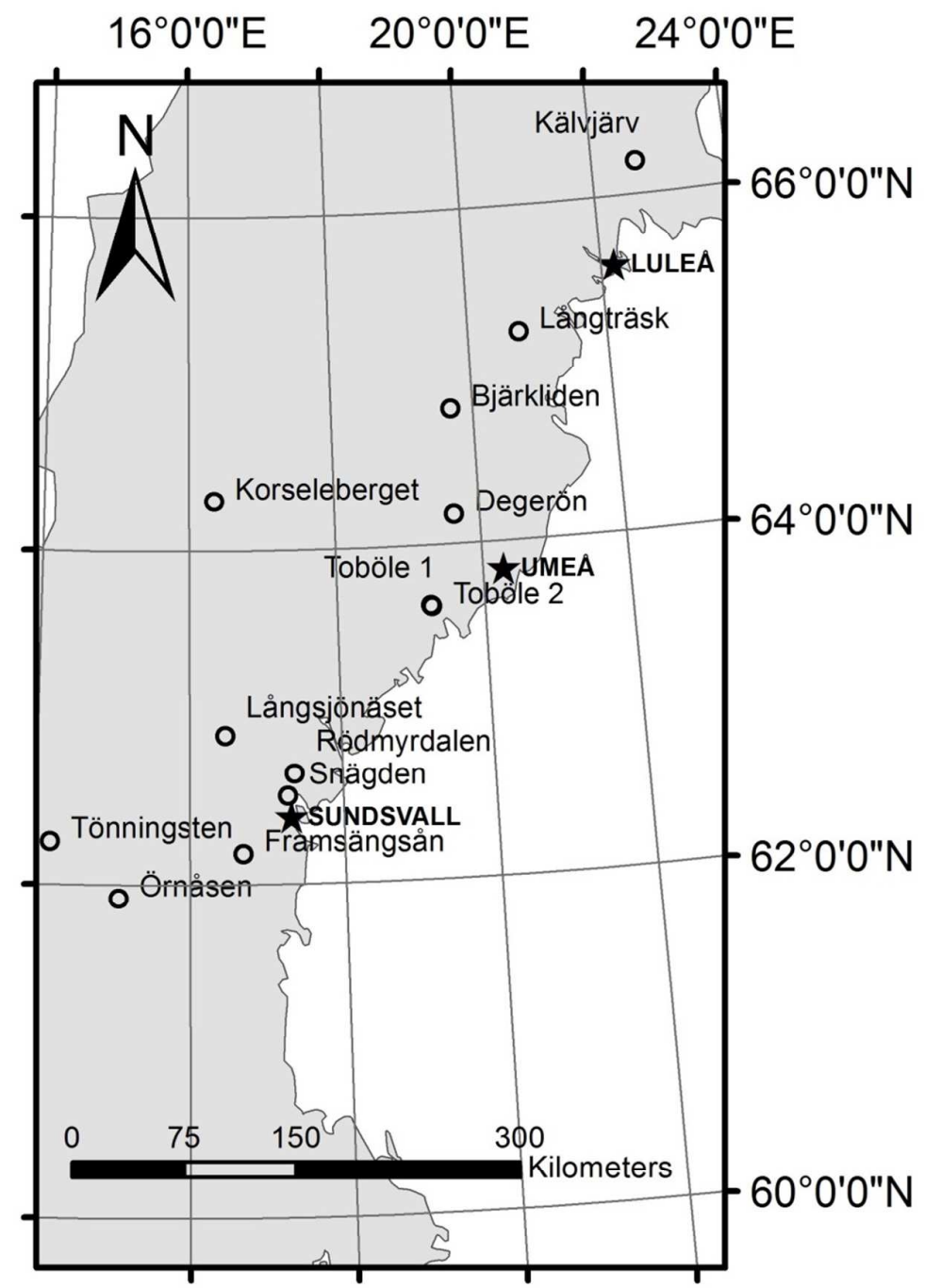

Fig. 1 


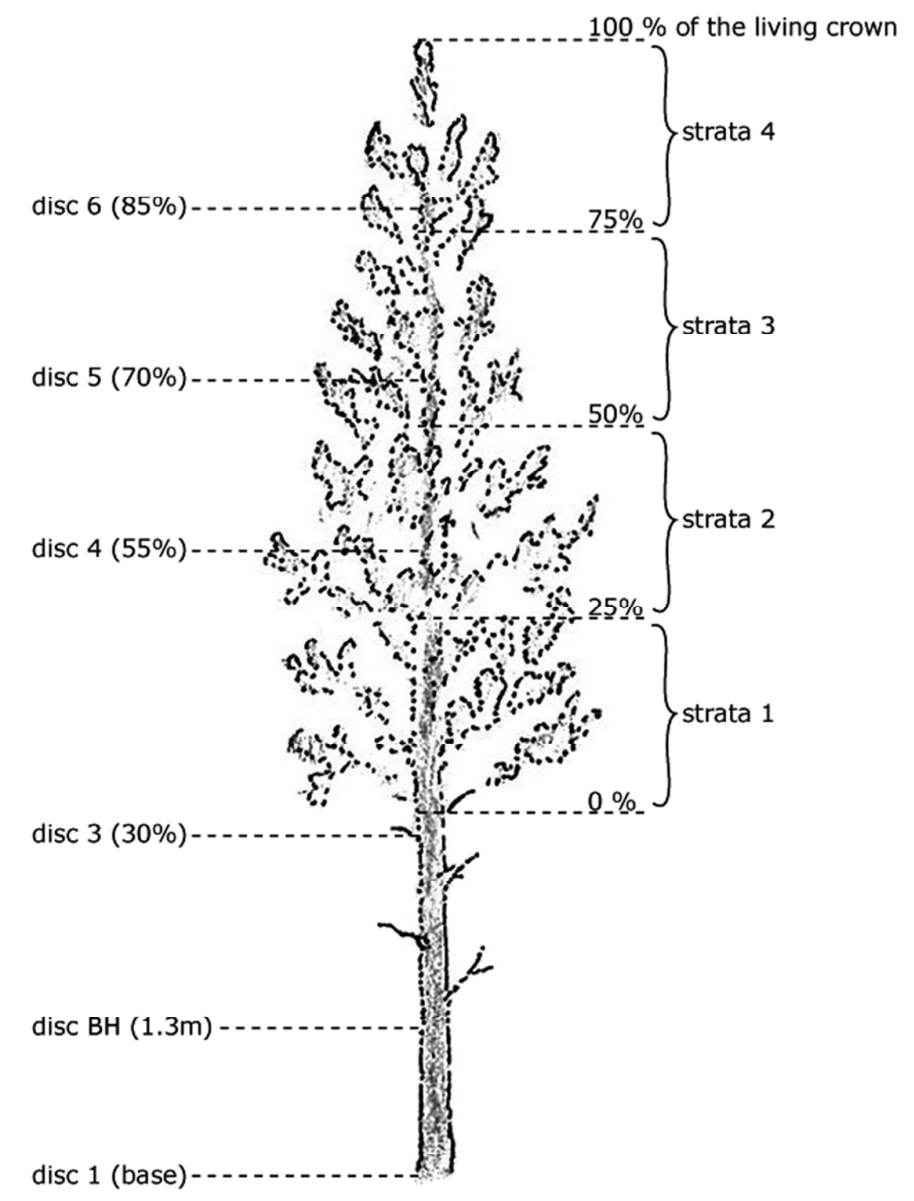

Fig. 2 

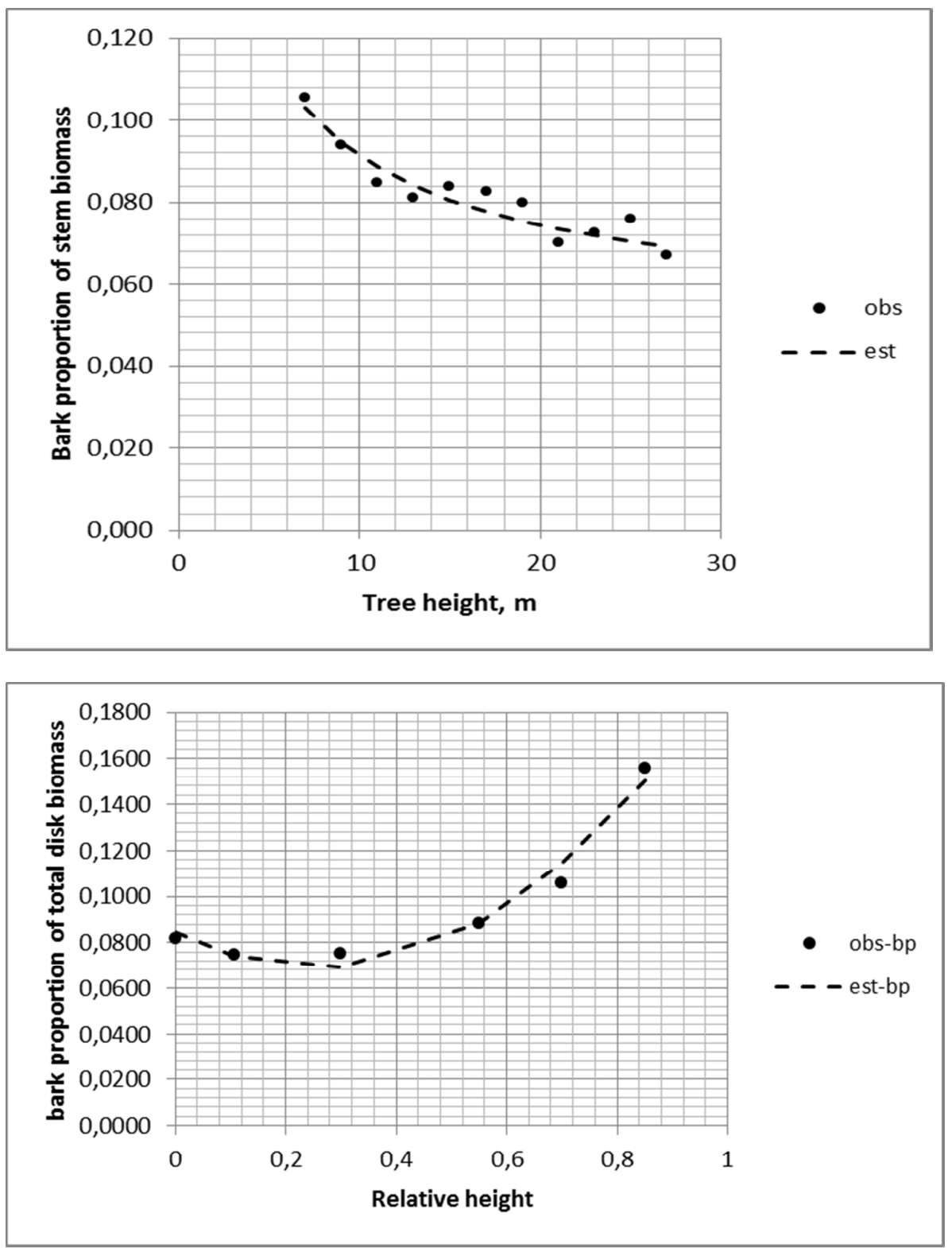

Fig. 3 


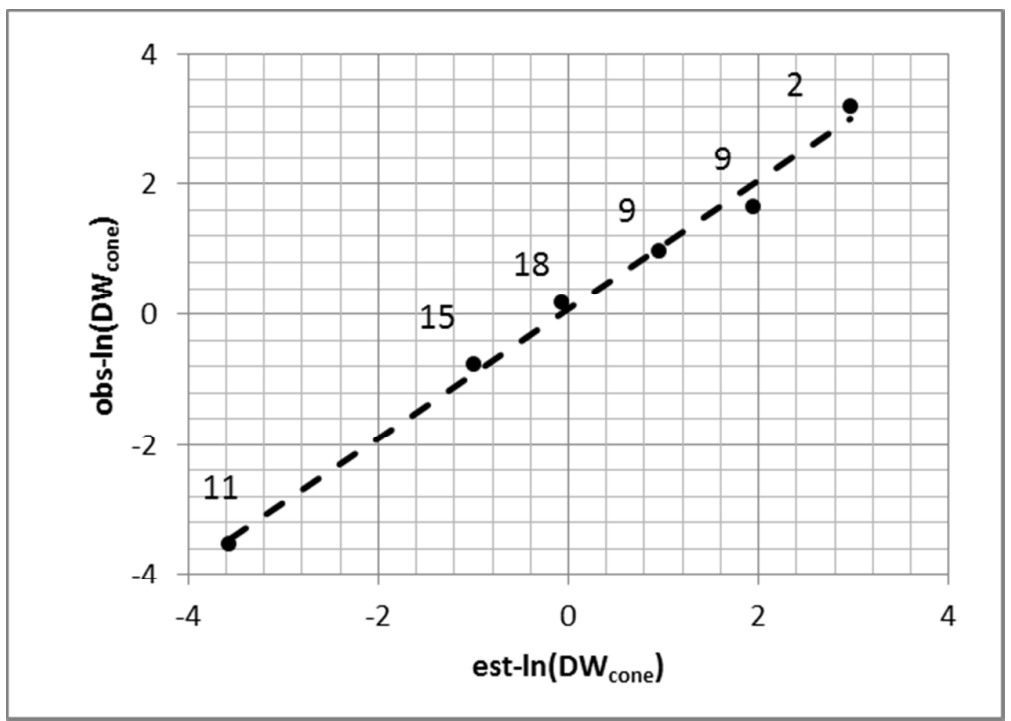

Fig. 4 